\title{
A 5 Years Systematic Overview of Working Capital Management towards Profitability of Alcholic and Non Alcholic Industries in Rwanda
}

\author{
Dr. Mbonigaba Celestin* \\ Business and Development Studies, Kibogora Polytechnic, Nyamasheke, Rwanda
}

\author{
DOI: $\underline{10.36348 / \text { sjef.2019.v03i12.002 }}$ \\ | Received: 07.12.2019 | Accepted: 15.12.2019 | Published: 23.12.2019 \\ *Corresponding author: Dr. Mbonigaba Celestin
}

\section{Abstract}

The topic of the study was to analyze working capital management on profitability of Consumer goods industries in Rwanda. The problem of the study was looking on how does working capital management could be a channel of profitability of consumer goods industries especially in Rwanda. The objectives of the study were to find out the extent to how inventory management affect the profitability of consumer goods industry, to evaluate the effectiveness of cash management on the profitability of consumer goods industry; and to analyze the influences of account receivable management on the profitability of consumer goods industries. The methodology used questionnaire, and documentary techniques, while methods of data analysis were descriptive statistic and linear regression analysis methods. Target population was 585 employees, while sample size was 59 of respondents from Bralirwa Plc, Skol industry and Urwibutso Enterprise as selected consumer goods industries in Rwanda. However, the findings of this study were presented in accordance with research objectives. Then, the results on the effects of Inventory management on the profitability of consumer goods industries were on the table 5 which confirmed in consumer goods industries, they make sure that every product needed to be sold on market is available in stock as confirmed on the rate of $93.2 \%$, and also the store room is well maintained in order to keep well goods on rate of $93.2 \%$. The findings on the effectiveness of cash management on the Profitability of Consumer goods industries were on table 6 which shown that petty cash is always available for solving little payments as confirmed by $96.6 \%$ of respondents. Cash are always disbursed after being approved by official workers was confirmed by $93.2 \%$ of respondents. The results on the influences of account receivable management on the profitability of Consumer goods industries were shown on table 7 that illustrated debts were only given after assessing the capacity of the purchaser to repay the debt as confirmed by $88.1 \%$ of respondents from selected consumer goods industries. The linear regression test between working capital management and profitability of Consumer goods industries confirmed that there is positive relationship between profitability and inventory management; cash management; and account receivable. As to recommend, the consumer goods industries in Rwanda should ensure that their personnel maintain a certain level of competence to perform duties effectively.

Keywords: Working capital management, Gross Profit Margin, Net profit Margin, Return on Assets, Return on Equity, and consumer goods industries.

Copyright @ 2019: This is an open-access article distributed under the terms of the Creative Commons Attribution license which permits unrestricted use, distribution, and reproduction in any medium for non-commercial use (NonCommercial, or CC-BY-NC) provided the original author and source are credited.

\section{GENERAL INTRODUCTION}

The objective of the firm is to maximize shareholder's wealth. The structure of working capital and liquidity analysis plays a key role in the process of wealth maximization of shareholders [1]. This is because most of the cash available to the firm is tied up in working capital. Borrowing additional cash to fund working capital of the firm is costly; in terms of interest charges and other related borrowing costs. The finance manager of the firm is therefore tasked with ensuring that the working capital of the firm is prudently managed in order to have a positive net present value to the shareholders. Guthmann, and Dougall [2], defined working capital as current assets minus current liabilities. The current refers to a time period of one year or less than one year.

According to Deloof [3] majority of the firms invested significant amount of cash in working capital and used trade payable as a key source of financing. So the way cash is handled can have a significant impact on the profitability of the firm. Lazaridis, and Tryfonidis [4], in their research concluded that 
operating profitability indicates how the management responds in terms of managing the working capital components. This is because they identified a negative relationship between the working capital components and the profitability. Raheman and Nasr [5], suggested that managers can increase the shareholders' value by reducing the receivable days and inventories days to a minimum level. Efficient working capital management is all about managing the working capital components effectively to meet the short-term obligations.

The concept of working capital management is concerned with managing working capital to promote a satisfying liquidity, profitability and shareholders' value. Working capital management is the ability to control effectively and efficiently the current assets and current liabilities in a manner that provides the firm with maximum return on its assets and minimizes payments for its liabilities. The short-term capital refers to the capital that companies use in their daily operations and it consists of companies' current assets and current liabilities. A well-managed working capital promotes a company's well-being on the market in terms of liquidity and also acts in favors the growth of shareholders' value [6].

The consumer Goods Industries of Africa, Excessive levels of current assets can easily result in a firm's realizing a sub-standard return on investment. However, firms with too few current assets may incur shortages and difficulties in maintaining smooth operations [7]. The profitability in industry can also be termed as the rate of return on investment. If there will be an unjustifiable over investment in current assets then this would negatively affect the rate of return on investment [8]. The basic purpose of managing working capital is controlling of current financial resources of a firm in such a way that a balance is created between profitability of the firm and risk associated with that profitability [9].

The management of Working capital is important to the financial health of business of all sizes. Working capital meets the short term financial requirements of a business enterprise. It is a trading capital not retained in the business in a particular form for longer than a year. The money invested in it changes form and substance during the normal course of business operations. The need for maintaining an adequate Working capital can hardly be questioned. This is the life blood of any business and must be managed properly to maintain the survival of a business. If it becomes weak, the business can hardly prosper and survive. Working capital starvation is generally credited as the major course if not a major course of small business failure in many developed and developing countries [10].

The success of a firm depends ultimately, on its ability to generate cash receipts in excess of disbursement. Given these peculiarities, efficient management of working capital and more recently good credit management practice is pivotal to the health and performance of a business [11]. The study conducted revealed that $60 \%$ enterprises suffer from cash flow problems. From such study there is the need for many industries to improve their return on capital employed (ROCE) by focusing on some critical areas such as cost containment, reducing investment in working capital and improving working capital efficiency. Based on the information from the above findings, there is a negative relationship between profitability and the cash conversion cycle, inventory receivable days, accounts payable days and accounts receivable days which are the components of working capital management.

Therefore, it seems that operational profitability dictates how managers or owners will act in terms of managing the working capital of the firm. The negative relationship between accounts receivables and firms' profitability suggests that less profitable firms will pursue a decrease of their accounts receivables in an attempt to reduce their cash gap in the cash conversion cycle. Likewise the negative relationship between number of days in inventory and corporate profitability suggests that in the case of a sudden drop in sales accompanied that mismanage inventory will tie up excess capital at the expense of profitable operations. Therefore managers can create profits for their companies by handling correctly the cash conversion cycle and keeping each different component (accounts receivables, accounts payables, inventory) to an optimum level.

In Rwandan industries, it is being reported that working capital play a great importance in profitability of the company, for instance in the study carried out by Ange S [12], indicated that; the statement of change in working capital, in the study area it was experienced an increase in net working capital of $6,477,645$ for the period of two years due to the fact that current asset continuously increased while current liabilities respectively reduced. The statement of change in working capital equally indicated that Sonatube experienced an increase in net working capital of $34,772,130$ for the period of two years (2011-2012) due to the fact that current asset continuously increased while current liabilities respectively reduced. According to the background, this study analyzes how working capital management influence profitability of consumer goods industries in Rwanda.

\section{PROBLEM STATEMENT}

Even though, manufacturing companies struggle to increase profitability by integrating working capital management in their working environment, yet some institution are found to be in bankrupt due to inappropriate or inadequate integration of working capital management in their operation or due to challenges in working environment. 
The study on the relationship between working capital management and profitability seems to be scanty yet; Rwanda boasts one of the fastest-growing economies on the continent. According to Masocha and Dzomonda [13], this economy has in the past experienced exponential growth consumer goods industries. These industries provide a remarkable milestone towards solving the country's development challenges such as unemployment, poverty and income inequality. And yet, several of these entities continue to fail due to their improper management of working capital and a resulting lack of the appropriate financing [13].

Hence, the dearth in study on working capital management creates a gap between policy makers and practitioners that warrants attention. In attempting to bridge this gap, this study assesses the impact of working capital management and profitability of Consumer goods industries in Rwanda using Consumer goods industries as a point of reference

\section{OBJECTIVE OF THE STUDY}

The purpose of this study is to analyze the effect of working capital management on the profitability of consumer goods industries in Rwanda

This study considered the following specific objectives:

- To find out the extent to how Inventory as part of WC impact on profitability of Consumer goods industries in Rwanda

- To evaluate the effectiveness of cash as part of WC on profitability of Consumer goods industries in Rwanda

- To analyze the influences of Account Receivable and payable as part of WC on profitability of Consumer goods industries in Rwanda

\section{LITERATURE REVIEW \\ Working Capital Management}

Working capital is an important tool for growth and profitability for corporations. If the levels of working capital are not enough, it could lead to shortages and problems with the day -to-day operations [7]. Working capital is also called net working capital and is defined as current assets less current liabilities [14].

Net working capital $=$ Current assets-current liabilities

The management of Working capital is important to the financial health of business of all sizes. Working capital meets the short term financial requirements of a business enterprise. It is a trading capital not retained in the business in a particular form for longer than a year. The money invested in it changes form and substance during the normal course of business operations. The need for maintaining an adequate Working capital can hardly be questioned. This is the life blood of any business and must be managed properly to maintain the survival of a business. If it becomes weak, the business can hardly prosper and survive. Working capital starvation is generally credited as the major course if not a major course of small business failure in many developed and developing countries [10].

The success of a firm depends ultimately, on its ability to generate cash receipts in excess of disbursement. Given these peculiarities, efficient management of working capital and more recently good credit management practice is pivotal to the health and performance of a business [11]. The study conducted revealed that $60 \%$ enterprises suffer from cash flow problems. From such study there is the need for many industries to improve their return on capital employed (ROCE) by focusing on some critical areas such as cost containment, reducing investment in working capital and improving working capital efficiency.

Both components of the working capital formula indicated above can be found on the balance sheet. Current assets can be found on the left side of the balance sheet and are those assets that generate cash within one year. Current assets are normally divided in cash and cash equivalents, short-term investments, trade and other receivables, prepaid expenses, inventories and work-in-progress. Current liabilities can be found on the right side of the balance sheet and are obligations which have to be met within one year. Current liabilities are divided in trade payables, short-term debt and accrued liabilities. 


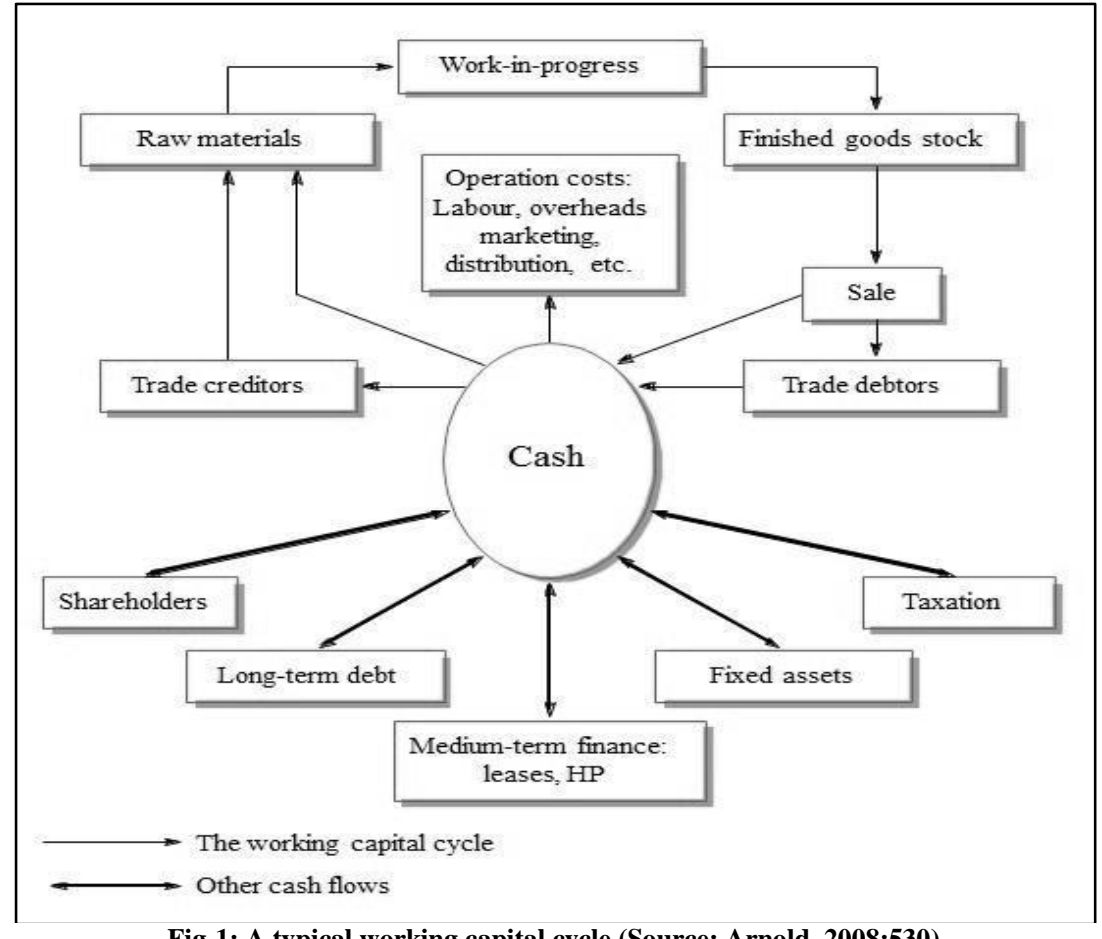

Fig-1: A typical working capital cycle (Source: Arnold, 2008:530)

To illustrate the working capital of a firm, the working capital cycle will now be discussed and can be seen in figure 1 on the previous page. The cycle begins with the purchase of raw materials which can be found in the inventory. Later on, these raw materials are transformed in finished goods. These goods are stocked in the inventory until they are sold to a customer. The sale can be purchased by cash or by trade credit. This trade credit provides a delay until the cash is received. With every step of the cycle there are associated costs, which are direct costs and opportunity costs.

The direct costs are the cost of capital invested in each part of the cycle, for example interest on the debt finance to sustain trade creditors. The opportunity costs are represented by the possible returns forgone by investing in working capital instead of some alternative investment opportunity [15].

The above discussed working capital and the cycle that it forms is managed by what is called Working Capital Management (WCM). WCM is part of the financial management of a firm, other parts are e.g. capital budgeting and capital structuring. The first two are mainly focused on the managing of long-term investments and returns. While WCM focuses mainly on the short-term financing and short-term investment decisions of firms [16]. Working capital management is vital for a firm, especially for manufacturing, trading and distribution firms, because in these firms WCM directly affect the profitability and liquidity. This is because for these firms it accounts for over half their total assets [5].
It is possible that inefficient WCM can lead to bankruptcy, even if the profitability of a firm is constantly positive [17]. A reason for this could be that excessive levels of current assets can easily lead to a below average return on investment for a firm [5]. An efficient WCM has to manage working capital in such a way that it eliminates risks of default on payment of short-term obligations on one side and minimalizes the change of excessive levels of working capital on the other side [18].

In the 1980's and prior to that period, working capital management was compartmentalized [19]. WCM was divided in cash, account payables and account receivables. In most firms, these compartments were managed by different managers on various different organizational layers [19]. But Sartoris and Hill [19] argued that there was a need for an integrated approach, where all the three compartments are combined. This led to the integration of the management of inventories, account payables and account receivables, called Working Capital Management (WCM), these parts will now be discussed individually.

Accounts receivables can be seen as short-term loans to customers given by the supplying firm. Giving these credit terms to customers are an important way of securing sales [15]. Although the total number of receivables on a balance sheet of a firm could be constant over time, its components are continually shifting and therefore careful monitoring is needed [20]. When the accounts receivables keep growing, funds are unavailable and therefore can be seen as opportunity costs. 
According to Berry and Jarvis [15] a firm setting up a policy for determining the optimal amount of account receivables has to take in account the following: The trade-off between the securing of sales and profits and the amount of opportunity cost and administrative costs of the increasing account receivables. The level of risk the firm is prepared to take when extending credit to a customer, because this customer could default when payment is due. The investment in debt collection management.

Account payables are the opposite of account receivables, instead of giving a credit on a sale, a firm receives a credit. Hampton and Wagner [21] explain account payables as follows: 'When a firm makes a purchase on credit, it incurs an obligation to pay for the goods according to the terms given by the seller. Until the cash is paid for the goods the obligation to pay is recorded in accounts payables. Account payables can be seen as a short-term loan, or in other words, a source of funding. The typical account payable policy is " 2 in 10 , net 30 ”.

This means that if a firm pays within 10 days it receives a discount of 2 percent, if not, the total bill has to be paid in thirty days. This means that a firm has to pay 2 percent for only 20 days, which is in fact a very expensive loan. To make this clearer the 2 percent can be transformed in an annual rate of 43 percent, which is enormous compared to normal annual rates. It is also possible that the policy is net 30 , which means that the due date is within thirty days, without any discount [22].

Instead of a source of funding, account payables or in other words using the trade credit term of a supplier can also be used to assess product quality [3, 23-26]. This assessment has to be done during the credit term and if the quality of the product is not satisfying, it can be sent back without paying the bill.

\section{The Inventory as part of WC impacts the profitability of Consumer goods industries}

There are several motives for lower or higher levels of inventories and highly depends on what business a company is in. The most widely and simple motive of managing inventories is the cost motive, which is often based on the Transaction Cost Economics (TCE) theory [27]. To be competitive, companies have to decrease their costs and this can be accomplished by keeping the costs of stocking inventory to a reasonable minimum [28]. This practice is also highly valued by stock market analysts [29]. There are also other motives of managing inventories such as:

\section{Higher inventory levels and variable demand}

The main motive of keeping high levels of inventories, which are raw materials, work-in progress, and finished goods, is to keep them as a buffer against demand fluctuations, production stoppages and other unexpected problems $[30,31]$. This motive is supported by evidence found by Cachon and Olivares [32], who found that among automotive companies in the US, inventories are used as safety stocks to better withstand demand fluctuations. Kahn (1987) also found evidence that companies increase their amount of stocks to decrease the probability of stock-outs when demand is high and thus inventory levels are determined by the fluctuations of sales of a company.

\section{Just-In-Time Inventory System}

Managerial decisions have a huge impact on the levels of inventories. During the seventies and eighties of the 20th century Japanese manufacturing companies increased their activities significantly in the U.S. markets. They also brought in new ideas of managing companies and since they increased their market shares substantially, it was apparent that some of these new ideas of managing were very successful. One of these ideas affected the way of managing inventories, which was called the Just-In-Time (JIT) inventory management system. The basic idea of this system was that companies should deliver products to their customer just-in-time. By doing this, companies won't have to have large amounts of stocks to be able to deliver goods. This saves a lot of costs concerning inventory stocking.

The question of whether companies in the U.S. did decrease their amount of stocks was studied by Chen et al., [33]. They found that a large amount of companies did significantly reduce their inventory levels. This reduction was mostly implemented on the levels of work-in-progress inventory. This decrease in inventory levels is also found by Rajagopalan, and Malhorta [34] who studied a number of industries in the manufacturing sector in the U.S.

\section{Higher inventory levels and production costs}

Another reason for companies to increase their finished goods inventory levels is to be able to produce in periods in which production costs are relatively low [35-37]. A comparable motive of increasing inventory levels is when companies can produce cheaper in batches, which can result in relatively high inventory levels.

Lieberman et al., [31] studied the determinants of inventory policies of automotive companies in the United States. They found that both technological and managerial factors have a significant influence on the determining of the levels of inventories. Technological factors, like longer setup and processing times increases the level of inventories. While the average price per piece of inventory decreases the inventory levels. They also found that managerial factors, like more employee training and problem solving training have a reducing effect on the inventory levels. Lieberman et al., [31] also found that when companies have a greater and 
more frequent communications with their supplier, the inventory levels will be lower. This finding is supported by Milgrom and Roberts [38] that view inventory and communication with a supplier as substitutes.

Also macro-economic conditions have a profound impact on the levels of the different types of inventories. Chen et al., [33] found that when interest rates are increasing, the levels of work-in-progress are decreased. Also evidence is found that inflation has a positive effect on the acquiring of raw materials. This is caused by the fact that companies wanted to buy these materials before the prices of these materials rise even more. They also found that when managers assume better economic conditions in the future, they increase the levels of finished goods [33].

\section{Inventory Management Theory}

The models that discuss inventory management are the Economic Order Quantity (EOQ), also known as Wilson Formula. The model was developed by Ford W. Harris in 1913, but Wilson, a consultant who applied it extensively, is given credit for his in-depth analysis. Economic Order Quantity is the order quantity that minimizes total inventory holding costs and ordering costs. The model only applies when demand for a product is constant over the year and each new order is delivered in full when inventory reaches zero. There is a fixed cost for each order regardless of the quantity ordered. There is also a holding cost for each unit held in storage. The model also assumes that the lead time is fixed, the purchase price of the item is fixed, there is no discount, the replenishment is made instantaneously, the whole batch is delivered at once and that only one product is involved.

The objective of Inventory management is to turn over inventory as quickly as possible without losing sales from stock-outs. It is an important aspect of working capital management because inventories themselves do not earn any revenue. Holding either too little or too much inventory incurs costs. Inventory is generally made up of three elements; raw materials, work-in-progress (WIP) and finished goods [39].

Minimizing of the raw materials is ideal in this particular part of working capital. However, this must be offset by the economic order quantities available from suppliers. The costs of carrying too much inventory are opportunity cost of foregone interest warehousing costs, damage and pilferage, obsolescence and insurance. The costs of carrying too little inventory are stock out (i.e. lost sales, delayed service), and ordering costs (i.e. freight, order administration and loss of quantity discounts).

On the other hand, work in progress concerns are when the product has left the raw material storage area, until it is declared for sale and delivery to customers. In this process the working capital must be considered in terms of reducing the buffer stocks, eliminating the production process, reducing the overall production cycle time. The raw materials and finished goods must be minimized in the production area. WIP must be carefully examined to justify how long it takes for products to be cleared for sale. This stage is normally done by the quality control (QC) procedures [40].

Finished goods refer to the stock sitting in the warehouse waiting for sale and delivery to customers. The owner/manager of the business should find what options are available to dispose of the slow-moving items. For example, should the stock be repacked or reprocessed, and sold at lower discount prices? JIT system can be used to minimize or eliminate both raw material stock and work in progress, as the stock is now in finished goods [41]. When using the JIT system, goods can be delivered directly to the production area, eliminating raw material storage areas. The purpose of using just-in-time approach is to have the supplier carrying the goods rather than being carried by the purchaser [41].

\section{Inventory Management and Profitability of Consumer Goods Industry}

Mathias B. Baveld [42] investigates how public listed firms in The Netherlands manage their working capital. A sample of 37 firms is used, which are among the fifty largest companies in The Netherlands. The working capital policies during the non-crisis period of 2004-2006 and during the Financial Crisis of 2008 and 2009 are compared. This comparison investigates whether companies have to change their non-crisis working capital policies when the economy is into a recession.

The results of this study indicate that, in crisis periods, firms don't need to change their working capital policy concerning accounts payables and inventory, if their goal is to enhance profit. For the working capital policy managing accounts receivables this is not the case. This is because during a crisis accounts receivables have a positive effect on a firm's profitability of the next year. These results are on shortterm basis. On the long-term, benefits of aiding customers during crisis periods are likely to grow, because future sales will still be there. Also, the risks taken by these aiding firms are relatively low and for large reputable firms it is also relatively cheap.

\section{The effectiveness of cash as part of WC on profitability of Consumer goods industries}

Cash can be used in operational expenses such as buying of stock, paying of salaries, rent and other administrative costs. At the same time, it may be used to purchase fixed assets. Holding cash is important in an organization because it will not have to raise an overdraft, call on shareholders to put in additional capital or raise debt. However, large amount of idle 
cash results in a lost opportunity to earn returns on it. This cash can be invested in a savings account, fixed deposit or government bonds for example, to earn an interest. Cash forecast should be carefully prepared to analyze the current and short term needs of cash for the firm.

\section{Cash Management Theory}

Cash management has been explained by several theories, some of which are; Baumol, model and Mille-Orr model. Baumol, model of cash management helps in determining a firm's optimum cash balance under uncertainty. According to the model, cash and inventory management are the same. William, J., Baumol, developed a model called the transaction demand for cash, an inventory theoretic approach. The model trades off between opportunity cost of carrying/holding cost and the transaction costs. The firms attempt to minimize the sum of holding cost and the cost of converting marketable securities to cash. The model enables companies to find out their desirable level of cash balance under certainty.

The model relies on trade-off between the liquidity provided by holding money (the ability to carry out transactions) and the interest foregone by holding one's asset in terms of non-interest bearing money. The assumptions are that, the company should be able to change the securities that they hold into cash keeping transaction costs constant, the company is capable of predicting its cash necessities with certainty, the company is aware of the cash holding cost which should be constant for a given period, the company should make its payments at regular intervals over a certain period regularly.

The limitations of this model are that it does not allow cash flow to fluctuate, overdraft is not considered and there are uncertainties in the pattern of future cash flows. The second model is the Miller-Orr model. This model helps companies to manage their cash while taking into consideration the fluctuation in daily cash flow. Here, the companies let their cash balance move within two limits; the upper limit and the lower limit. The companies buy or sell their marketable securities only if the cash balance is equal to any one of these.

When the cash balances touch the upper limit, it purchases a certain number of saleable securities that help them to come back to the desirable level. If the cash balance of the company reaches the lower level, then the company trades its saleable securities and gathers enough cash to fix the problem. It is normally assumed that the average value of the distribution of net cash flow is zero. It is also understood that the distribution of net cash flow has a standard deviation. The model also assumes that the distribution of cash flow is normal. The model is applicable in finding the approximate prices at which the saleable securities could be sold or bought, deciding the minimum possible levels of desired cash balance, checking the rate of interest and calculating the standard deviation of regular cash flows [16].

\section{Quantity Theory of Money}

This is an economic theory which proposes a positive relationship between changes in the money supply and the long-term price of goods. It states that increasing the amount of money in the economy will eventually lead to an equal percentage rise in the prices of products and services. The calculation behind the quantity theory of money is based upon Fisher Equation. According to the quantity theory, money is held only for the purpose of making payments for current transactions. Fishers in 1911 proposed a version of the quantity theory of money that can be explained in terms of the equation below; $\mathrm{MV}=\mathrm{PT}$. Where $\mathrm{M}$ is the nominal stock of money in circulation, $\mathrm{V}$ is the transaction velocity of money. $\mathrm{P}$ represents the average price level and $\mathrm{T}$ is the number of transactions that take place during the time period. This theory originated in the sixteenth century as European economists noticed higher levels of inflation associated with importing gold or silver from the Americas. According to how the formula is derived, holding the transaction volume and velocity of money constant, any increases in the money supply will yield a proportional increase in the average price level.

\section{Keynesian Theory of Money}

The traditional quantity theory of money and the quantity equations do not show how a change in the quantity of money reacts upon the price level. Keynes tries to tackle this aspect of the problem in his General Theory by a restatement of the quantity theory. In doing so, he tried to integrate the theory of money with the theory of employment. To Keynes, the effect of changes in the quantity of money on the price level (in turn, the value of money) should be visualized through the interrelated effect on the wage rate, income, investment, employment, etc. Thus, an increase in the quantity of money will have no effect on prices, so long as there is any unemployment, and that employment will increase in exact proportion to any increase in effective demand brought about by the increase in the quantity of money. While, as soon as full employment is reached, wage rate and price will increase in exact proportion to the increase in effective demand. Hence, Keynes enunciated the quantity theory of money as follows: "So long as there is unemployment, employment will change in the same proportion as the quantity of money."

The general theory of employment, interest and money identified three reasons why liquidity is important; the speculative motive, the precautions motive and the transaction motive. The speculative motive is the need to hold cash to be able to take advantage. For example, bargain purchase and 
favorable exchange rates fluctuations in the case of if international firms. For most firms, reserve borrowing ability and marketable securities can be used to satisfy speculative motives. Precautionary motive is the need for a safety supply to act as a financial reserve. The transaction motive is the need to have cash on hand to pay bills. Transaction related needs come from collections activities of the firm. The disbursement of cash includes the payments of wages and salaries, trade debts, taxes etc [17].

\section{Baumol Model of Cash Management}

Baumol model of cash management helps in determining a firm's optimum cash balance under certainty. It is extensively used and highly useful for the purpose of cash management. As per the model, cash and inventory management problems are one and the same. William J. Baumol developed a model (The transactions Demand for Cash: An Inventory Theoretic Approach) which is usually used in Inventory management \& cash management. Baumol model of cash management trades off between opportunity cost or carrying cost or holding cost $\&$ the transaction cost. As such firm attempts to minimize the sum of the holding cash \& the cost of converting marketable securities to cash. At present many companies make an effort to reduce the costs incurred by owning cash. They also strive to spend less money on changing marketable securities to cash.

The Baumol model of cash management is useful in this regard. The Baumol model enables companies to find out their desirable level of cash balance under certainty. The Baumol model of cash management theory relies on the tradeoff between the liquidity provided by holding money (the ability to carry out transactions) and the interest foregone by holding one's assets in the form of non-interest bearing money. The key variables of the demand for money are then the nominal interest rate, the level of real income which corresponds to the amount of desired transactions and to a fixed cost of transferring one's wealth between liquid money and interest bearing assets [44].

\section{The Pecking Order Theory}

In corporate finance, pecking order theory (or pecking order model) postulates that the cost of financing increases with asymmetric information. Financing comes from three sources, internal funds, debt and new equity. Companies prioritize their sources of financing, first preferring internal financing, and then debt, lastly raising equity as a "last resort". Hence: internal financing is used first; when that is depleted, then debt is issued; and when it is no longer sensible to issue any more debt, equity is issued. This theory maintains that businesses adhere to a hierarchy of financing sources and prefer internal financing when available, and debt is preferred over equity if external financing is required (equity would mean issuing shares which meant 'bringing external ownership' into the company). Thus, the form of debt a firm chooses can act as a signal of its need for external finance. The pecking order theory is popularized by Myers and Majluf [45] when he argues that equity is a less preferred means to raise capital because when managers (who are assumed to know better about true condition of the firm than investors) issue new equity, investors believe that managers think that the firm is overvalued and managers are taking advantage of this overvaluation. As a result, investors will place a lower value to the new equity issuance.

\section{Cash Management and profitability of consumer goods industries}

Omesa et al., [46] examined the relationships between Working Capital Management and Corporate Performance of manufacturing firms listed on the Nairobi securities exchange. A sample of 20 companies whose data for 5 years from 2007-2011 was selected. They used the Principal Components Analysis (PCA) and multiple regressions to analyze data sets. They found out that, working capital proxies; Cash Conversion Cycle, Average Collection Period and control variables Current Liabilities, Net Working Capital Turnover Ratio and Fixed Financial Ratio were significant at $95 \%$ confidence ( $\mathrm{p}$ values are $<0.05$ ) to performance as measured by Return on Equity (ROE).

Smith and Begemann [47] emphasized that those who promoted working capital theory shared that profitability and liquidity comprised the salient goals of working capital management. The problem arose because the maximization of the firm's returns could seriously threaten its liquidity, and the pursuit of liquidity had a tendency to dilute returns. This article evaluated the association between traditional and alternative working capital measures and return on investment (ROI), specifically in industrial firms listed on the Johannesburg Stock Exchange (JSE). The problem under investigation was to establish whether the more recently developed alternative working capital concepts showed improved association with return on investment to that of traditional working capital ratios or not. Results indicated that there were no significant differences amongst the years with respect to the independent variables. The results of their stepwise regression corroborated that total current liabilities divided by funds flow accounted for most of the variability in Return on Investment (ROI).

The statistical test results showed that a traditional working capital leverage ratio, current liabilities divided by funds flow, displayed the greatest associations with return on investment. Well known liquidity concepts such as the current and quick ratios registered insignificant associations whilst only one of the newer working capital concepts, the comprehensive liquidity index, indicated significant associations with return on investment. All the above studies provide us a solid base and give us idea regarding working capital 
management and its components. They also give us the results and conclusions of those researches already conducted on the same area for different countries and environment from different aspects.

Deloof [3] discussed that most firms had a large amount of cash invested in working capital. It can therefore be expected that the way in which working capital is managed will have a significant impact on profitability of those firms. Using correlation and regression tests he found a significant negative relationship between gross operating income and the number of days accounts receivable, inventories and accounts payable of Belgian firms. On basis of these results he suggested that managers could create value for their shareholders by reducing the number of days' accounts receivable and inventories to a reasonable minimum. The negative relationship between accounts payable and profitability is consistent with the view that less profitable firms wait longer to pay their bills.

Ghosh and Maji [48] in this paper made an attempt to examine the efficiency of working capital management of the Indian cement companies during $1992-1993$ to 2001-2002. For measuring the efficiency of working capital management, performance, utilization, and overall efficiency indices were calculated instead of using some common working capital management ratios. Setting industry norms as target-efficiency levels of the individual firms, this paper also tested the speed of achieving that target level of efficiency by an individual firm during the period of study. Findings of the study indicated that the Indian Cement Industry as a whole did not perform remarkably well during this period.

Shin and Soenen [1] highlighted that efficient Working Capital Management (WCM) was very important for creating value for the shareholders. The way working capital was managed had a significant impact on both profitability and liquidity. The relationship between the length of Net Trading Cycle, corporate profitability and risk adjusted stock return was examined using correlation and regression analysis, by industry and capital intensity. They found a strong negative relationship between lengths of the firm's net trading cycle and its profitability. In addition, shorter net trade cycles were associated with higher risk adjusted stock returns.

Eljelly [49] elucidated that efficient liquidity management involves planning and controlling current assets and current liabilities in such a manner that eliminates the risk of inability to meet due short-term obligations and avoids excessive investment in these assets. The relation between profitability and liquidity was examined, as measured by current ratio and cash gap (cash conversion cycle) on a sample of joint stock companies in Saudi Arabia using correlation and regression analysis. The study found that the cash conversion cycle was of more importance as a measure of liquidity than the current ratio that affects profitability. The size variable was found to have significant effect on profitability at the industry level. The results were stable and had important implications for liquidity management in various Saudi companies. First, it was clear that there was a negative relationship between profitability and liquidity indicators such as current ratio and cash gap in the Saudi sample examined. Second, the study also revealed that there was great variation among industries with respect to the significant measure of liquidity.

The effect of aggressive working capital policy on financial ratios was examined by Boisjoly [50], who found that cash flow per share significantly improved due to aggressive management of working capital and that productivity increased. The relationship between profitability and working capital management for firms listed on the Athens Stock Exchange was examined by Lazaridis and Tryfonidis [4]. The results showed significant relationship between operational profitability and the cash conversion cycle, the results also showed that executives can increase profitability of their firms by correctly handling the individual components of working capital to an optimal level.

\section{The Account Receivable and payable Management and Profitability of Consumer goods industries}

The combined effect of the accounts receivables, accounts payables and inventories have on a firm's profitability, will be tested using the Cash Conversion Cycle (CCC). The effect is has on firm's profitability during non-crisis years is expected to be negative, as is explained in the previous paragraph. This negative relation is still expected to exist during a crisis period, because the effects on profitability of accounts payables and inventories are not expected to change in times of a crisis. Furthermore the expected change of the effect of the accounts receivables is expected to be not enough to alter the negative effect the CCC has on a firm's profitability.

When a company sells goods or services on credit, it records this as accounts receivable in its ledgers and the balance sheet. The period of time given to customers to pay for goods and/or services is called the credit period. Companies usually carry out a credit analysis to gauge who are paying on time and who are not. By receiving cash early, companies could improve their life-blood. Collecting the cash too early and not providing generous credit terms might hamper business sales in the long run as customers might turn to competitors to get their goods. Another option to improve working capital and to get cash early is to sell and handover the trade receivables to a factoring company. The factoring company will discount the trade receivables as their commission. However, as mentioned earlier, there might be a risk of engaging factors, as they might treat the credit customers harshly 
when they don't pay-up on time. This might harm trade relations with the company that gave on credit [51].

When a company buys good on credit, it becomes an account payable by the buying firm to the selling firm. Most companies, especially retail and manufacturing, buy goods on credit and record it as a liability that has to be paid. A company can extend its credit policy based on the relationship between the suppliers. Accounts payable is a form of short term debt, and should be effectively managed to ensure that payments are made on time and that creditor relationship is well maintained.

Arnold [52], says that buying good on credit and then selling them on credit to customers is a cheaper form of finance than an organization taking a bank overdraft to finance credit sales. Obtaining trade credit has benefits, such as, debtors does not have to be financed by short term debt, also if the credit period is long, the cash could be used to buy inventory for sales.

\section{Account Receivables Management Theory}

Several theoretical studies attempt to explain why firms extend trade credit to customers. The theories that explain this are the transaction cost theory. Ferris [53] argues that the existence of trade credit allows flexibility in payment and makes it possible to cumulate payment of several successive supplies to be paid at once, thus leading to saving of transaction costs. Furthermore, trade credits allow buyers to hold smaller cash balances and save money accordingly. Other versions relate to the seasonality in the consumption pattern of the selling firm. The other is the financial model based on capital market imperfections relating to information asymmetries.

Schwartz [54] suggests that firm with better access to institutionalized capital and with lower cost of financing offers trade credits to customers with high costs when borrowing from financial intermediaries. It may also be argued that trade credit can help to mitigate credit rationing while providing a signal on buyers' good quality to financial intermediaries, Frank and Maksimovic [55]. Other models suggest that the seller has an advantage over financial intermediaries in information acquisition and controlling of the buyer.

\section{Account Receivable Management and profitability of consumer goods industry}

Gill, B, et al., [56] in their research selected 88 companies from New York. They carried out their research between 2005 and 2007. The independent variables were; receivable days, payable days, inventory days, natural logarithm of sales and gearing. The dependent variable was gross operating income. They used regression analysis to evaluate the variables. They concluded that there is a negative relationship between the profitability and receivable days. Further they also concluded that the relationship between the cash conversion cycle and profitability is positive.

\section{Determinants of Profitability}

A profitable firm is better able to withstand negative shocks and contribute to the stability of the financial system. The profitability of a firm is affected by numerous factors. These factors include elements internal to each firm and several important external forces shaping earnings performance. Many firms are taking several measures to enhance profitability across the sectors. We have seen firms maximizing revenue growth to enhance profitability while other firms adopt a cost management strategy as revenue growth is not feasible in their industries due to several factors like competition, price regulations etc. It is therefore important to understand the determinants of firm's profitability.

This is essentially important in the light of the above notable changes that always occur in the operating environment of the firms. Across all industries, the determinants of profitability are well observed and explored as it is increasingly important to strengthen the foundations of domestic financial system as a way to buildup flexibility for capital flow volatility. In the past, researchers investigated the determinants of profitability of a firm. A good number of researchers considered only the firms' characteristics, whereas others included the financial structure and macroeconomic factors as well. In all these studies, contributions had been made in determining the factors that shape the profitability of firms.

More recent studies distinguish between managerial (internal) and environmental (external) factors that affect a firm's profitability. Literature has argued that the overall market structure and entry barriers constitute the main external force driving profits. Market structure (represented by regulatory conditions or concentration) is one of the external influences that affect bank profitability; others include trade interdependence, economic growth, inflation, market interest rates and ownership structure. The internal factors according to past studies include capital ratio, credit risk, productivity growth and size of the firm. A number of other studies have examined firms' profitability in an effort to isolate the factors that account for differences in profitability.

Studies have linked firms' earnings and various aspects of their operating performance to profitability. A second set of studies focused on the relationship between a firm's earnings performance and balance sheet structure and profitability. A third body of literature examined the impact of regulatory and macroeconomic factors on overall firms' profitability. The main conclusion emerging from past studies is that internal factors explain a large proportion of firms' profitability; nevertheless external factors have also had 
an impact on their profitability. Overall, operational efficiency is the major factor in determining performance across industries. Among the internal factors are the management controllable factors which are the firm's specific financial ratios representing cost efficiency, liquidity, asset quality, and capital adequacy.

Eljelly [49] elucidated that efficient liquidity management involves planning and controlling current assets and current liabilities in such a manner that eliminates the risk of inability to meet due short-term obligations and avoids excessive investment in these assets. The relation between profitability and liquidity was examined, as measured by current ratio and cash gap (cash conversion cycle) on a sample of joint stock companies in Saudi Arabia using correlation and regression analysis. The study found that the cash conversion cycle was of more importance as a measure of liquidity than the current ratio that affects profitability. The size variable was found to have significant effect on profitability at the industry level. The results were stable and had important implications for liquidity management in various Saudi companies. First, it was clear that there was a negative relationship between profitability and liquidity indicators such as current ratio and cash gap in the Saudi sample examined. Second, the study also revealed that there was great variation among industries with respect to the significant measure of liquidity.

For Lincoln [57], profitability is considered as a measure of financial performance. It is simply the capacity to make a profit which is what left over from income earned after you have deducted all costs and expenses related to earning the income.

\section{Return on Assets}

This metric measures how effectively the company produces income from its assets. You calculate it by dividing net income (NI) for the current year by the value of all the company's assets (A) and multiplying the quotient by 100: Return on Assets $=$ Net Income/Assets x 100 or

$$
R O A=\frac{N I}{A} * 100
$$

\section{Return on Equity}

Return on equity measures how much a company makes for each dollar that investors put into it. You calculate it by taking the net income earned by the amount of money invested by shareholders and multiplying the quotient by 100: Return on Equity=Net Income/Shareholder Investment x 100

$$
R O E=\frac{N I}{S I} * 100
$$

\section{Net Interest Margin}

This is net interest as a percentage of turnovers. It is margin narrower measure of interest, as it takes all costs into account, not just direct ones. All overheads as well as interest and tax payments, are included in the interest calculation.

$$
\mathrm{NIM}=\frac{N P}{\text { turnover }} * 100
$$

\section{Gross profit Margin}

Gross margin tells you about the profitability of your goods and services. It tells you how much it costs you to produce the product. It is calculated by dividing your gross profit (GP) by your net sales (NS) and multiplying the quotient by 100: Gross Margin = Gross Profit/Net Sales x 100

$$
G P M \%=\frac{G P}{N S} * 100
$$

\section{Critical Review and Gap Identification}

Above all, the literature review indicates that working capital management has A GREAT impacts on profitability, liquidity and performance of a firm. The efficiency of a company's working capital management has lasting impact on company performance. Cash Conversion Efficiency Days Operating Cycle and Days Working Capital in the overall working capital performance criterion not only helps in performance evaluation but also will capture the dynamics of riskreturn trade off. Hence, economic value added, Tobin's $\mathrm{Q}$ ratio, return on invested capital (ROI); return on equity (ROE), and ROA (Return on Assets) are the most important measure of firm's performance and profitability. Indeed, the company's inventory management policy, debtors' management policy and creditors' management policy play an important role in its profitability performance.

Even if, the literature review indicated that working capital management has impact on the profitability, liquidity and performance of a firm but there is vagueness regarding the appropriate variables, effect size measures that might serve as proxies for working capital management as a whole. Hence, literature review consisting some of previous studies though limited in scope, methodology and overall output. Likewise, lack of not incorporating all relevant and most important variables (independent and control) used to measure both working capital and firm's performance, it creates difficulty for comparability of studies conduct in similar areas.

Moreover, it is evident from the literature that not much of the studies have been able enough to develop a model that will assist managers to establish an optimum working capital under different operating environments or even Consumer Goods Industries. Instead the literature and studies suggest the existence of an optimum level without necessarily suggesting the same level or how to be established. As a result, first the researcher tried to identify major relevant variables which are missed or not included in previous studies. 
So, as to reveal the contents or new variables, all variables would enhance the findings and fill the problem of missing important variables which was observed in previous studies and in their dimensions in depth. The gap left by previous literature is that there is no study among above mentioned which addressed the study on working capital management and profitability of Consumer goods industries in Rwanda as geographical gap.

\section{METHODOLOGY \\ Research Design}

The study adopted an exploratory approach using a descriptive survey design. A descriptive research design determines and reports the way things are [58]. Creswell [59] observes that a descriptive research design is used when data are collected to describe persons, organizations, settings or phenomena. The design also has enough provision for protection of bias and maximized reliability [60].

Descriptive design uses a preplanned design for analysis [58]. In this study, inferential statistics and measures of central, dispersion and distribution is applied. Research design is a roadmap of how one goes about answering the research questions [61]. Sekaran [62], states that a good research design had a clearly defined purpose, and had consistency between the research questions and the proposed research method. Mugenda \& Mugenda [58] define this as simply the framework or blue print for the research, Orodho [63] define the research design as a framework for the collection and analysis of data that is suited to the research question. Orodho [63] defines research design as the scheme, outline or plan that is used to generate answers to the research problem.

\section{Study Population}

Population refers to the entire group of people or things of interest that the researcher wishes to investigate, Sekaran [62]. Mugenda \& Mugenda [58], defines population as an entire group of individual or objects having common observable characteristic. Data available from the Ministry of Trade and industry 2017 reveal that there are only 4 consumer goods industries named BRALIRWA Plc, INYANGE Industry, SKOL Brewery and Enterprise Urwibutso. Therefore, the study targeted the 585 staff in those industries.

\section{Determination of the Sample size}

The sampling frame describes the list of all population units from which the sample was selected [64]. It is a physical representation of the target population and comprises all the units that are potential members of a sample [60].

Kerlinger [65], indicates that a sample size of $10 \%$ of the target population is large enough so long as it allows for reliable data analysis and allows testing for significance of differences between estimates. The sample size depends on what one wants to know, the purpose of the inquiry, what is at stake, what was useful, what had credibility and what can be done with available time and resources [66]. Therefore, a proportionate sample size of approximate 59 respondents which is $10 \%$ of the population was selected using a stratified random sampling technique from the identified sample in Table below.

Table-1: Sample composition

\begin{tabular}{|l|l|l|l|l|}
\hline SN & Industry name & Number of staff & Frequency & Percentage \\
\hline 1 & BRALIRWA Plc & 159 & 16 & $10 \%$ \\
\hline 2 & INYANGE Industry & 167 & 17 & $10 \%$ \\
\hline 3 & SKOL Brewery & 140 & 14 & $10 \%$ \\
\hline 4 & Enterprise Urwibutso & 119 & 12 & $10 \%$ \\
\hline \multicolumn{2}{|l}{ Total } & $\mathbf{5 8 5}$ & $\mathbf{5 9}$ & $\mathbf{1 0 \%}$ \\
\hline
\end{tabular}

Source: MINEACOM report, 2018

\section{Data Collection Methods}

Creswell [67] defines data collection as a means by which information is obtained from the selected subjects of an investigation.

\section{Questionnaire}

It is an instrument consisting of a series of questions and other prompts for the purpose of gathering information from respondents. Questionnaires provide a relatively cheap, quick and efficient way of obtaining large amounts of information from a large sample of people. Data can be collected relatively quickly because the researcher would not need to be presented when the questionnaires are completed.
During this study, the questionnaires were distributed to the employees from consumer goods industries. The information was collected from questionnaire are filled by respondents selected. The questionnaire was composed by close end questions where we expect participation rate of $100 \%$ for responding the questions. To design questionnaire, the researcher used likert three scales to assess the appreciations of respondents on WCM and profitability.

\section{Interview Guide}

It consists by asking with the proper voice on the purpose of exchanging ideas between the interviewer and the interviewee. An interview is a manner in which the researcher tries to get information from interviewee [68]. During this study, the 
importance of this instrument is a willing to provide honest answers by confirming the data provide from questionnaire. The interview was addressed to the executive management of Consumer goods industries

\section{Documentation}

Documentary technique was used by the researcher as materials which contain the information about a phenomenon that researcher wishes to study. In this study, the documents targets were annual reports about WCM and profitability where they were consulted for the purpose of obtaining secondary information relevant to the subject matter.

\section{Data Collection Procedure}

In preparation to undertake the study, a research permit was obtained from IST. This is in line with the legal aspects of conducting research in Rwanda. Moreover, authority to collect data made respondents more convinced to relay the needed information. The researcher then made visits to the identified consumer goods industries for this research for coordination purposes with the respective authorities. Permission to conduct research in a particular industry was obtained from the executive officer. The researcher issued the questionnaires to respondents concerned and arranged with them the date for collecting the completed questionnaires.

\section{Pilot Test}

Cooper \&Schindler [69] indicated that a pilot test is conducted to detect weaknesses in design and instrumentation and to provide proxy data for selection of a probability sample. According to Babbie (2004), a pilot study is conducted when a questionnaire is given to just a few people with an intention of pre-testing the questions. Pilot test is inactivity that assists the research in determining if there are flaws, limitations, or other weaknesses within the interview design and allows him or her to make necessary revisions prior to the implementation of the study [70].

A pilot study was undertaken on 6 staff from MINEACOM that were chosen purposively as parent ministry overseeing trade policies to test the reliability and validity of the questionnaire. The rule of thumb is that $1 \%$ of the sample should constitute the pilot test $[71,59]$. The proposed pilot test was within the recommendation.

\section{Reliability of Research Instruments}

Reliability is the consistency of a set of measurement items while validity indicates that the instrument is testing what it should [72]. Reliability is the consistency of your measurement, or the degree to which an instrument measures the same way each time it is used under the same condition with the same subjects. In short, it is the probability of your measurement. A measure is considered reliable if a person's score on the same test given twice is similar.
It is important to remember that reliability is not measured, it is estimated. Reliability does not, however, imply validity because while scale may be measuring something consistently, it may not necessarily be what it is supposed to be measuring. The researcher used the most common internal consistency measure known as Cronbach's alpha $(\alpha)$. It indicates the extent to which a set of test items can be treated as measuring a single latent variable [72].

The recommended value of 0.7 was used as a cut-off of reliabilities. Cronbach's alpha is a general form of the Kunder-Richardson (K-R) 20 formulas used to access internal consistency of an instrument based on split-half reliabilities of data from all possible halves of the instrument. It reduces time required to compute a reliability coefficient in other methods [58].

The Kunder-Richardson (K-R) 20 is based on the following formula which was used in order to make sure that questionnaire is valid and reliable. Validity Index (CVI) where the researcher computed the validity coefficient. The content validity index is equal to the total number of valid items divided by the total number of items. Thus, the content validity index (CVI) $=\mathrm{R} / \mathrm{R}+\mathrm{IR}$ whereby $\mathrm{R}=$ relevant questions; $\mathrm{IR}=$ irrelevant questions. The instrument was certified the valid when its minimum content validity index is at least at 0.7 [73].

The instrument was certified the valid when its minimum content validity index is at least at 0.7

Total number of questionnaire $=6$

Total number of valid questionnaire $(\mathrm{R})=5$

Total number of Irrelevant questionnaire (IR) $=1$

Content validity index $=5 /(5+1)=0.833$

The content validity index is 0.833 ; thus, the instruments are certified valid because the content validity index is more than the required minimum which is 0.7 .

\section{Reliability}

In this research, MINEACOM is chosen before going at consumer goods industries where the distribution of 6 samples questionnaire was be done for pre-testing the reliable result. Thereafter, the result obtained is analyzed by using SPSS Version 20 for pretesting of Cronbach's Alpha between the variables under study.

Table-2: Legend Cronbach's Test of Reliability
\begin{tabular}{|l|l|}
\hline Cronbach's alpha & Internal consistency \\
\hline $\boldsymbol{\alpha} \geq \mathbf{0 . 9}$ & Excellent \\
\hline $\mathbf{0 . 8} \leq \boldsymbol{\alpha}<\mathbf{0 . 9}$ & Good \\
\hline $\mathbf{0 . 7} \leq \boldsymbol{\alpha}<\mathbf{0 . 8}$ & Acceptable (Surveys) \\
\hline $\mathbf{0 . 6} \leq \boldsymbol{\alpha}<\mathbf{0 . 7}$ & Questionable \\
\hline $\mathbf{0 . 5} \leq \boldsymbol{\alpha}<\mathbf{0 . 6}$ & Poor \\
\hline
\end{tabular}




\section{Validity of Research Instruments}

An instrument is valid if it measures what it is intended to measure and accurately achieves the purpose for which it was designed [74, 75]. Validity is a matter of degree and no test instrument is perfectly valid, Patten [74]. Validity involves the appropriateness, meaningfulness, and usefulness of inferences made by the researcher on the basis of the data collected [75]. Content validity is determined by judgments on the appropriateness of the instrument's content, Patten [74]. There are three principles to improve content validity: Use of a broad sample of content rather than a narrow one, to emphasize on important material, and to write questions to measure the appropriate skill [74]. The three Principles were considered in this study. The researcher discussed the research instrument with MINEACOM as parent ministry to test its validity.

\section{Data Management}

Data collected was screened to find out any missing values or errors that could be corrected. Before any statistical analyses were done, the researcher checked for normality of the variables under the study.

The assumption is that the variables are normally distributed. According to Ali, Namusonge and Sakwa [76], the assumptions and application of statistical tools as well as suitability of the tests are important aspects for statistical analysis. When results are verified data inspires stakeholder confidence and give reliable inferences and trustworthy interpretations for policy making. To check for normality, the study adopted the One-sample Kolmogorov-Smirnov test, Skewness and Kurtosis test, and Durbin-Watson (Auto correlation test).

\section{Processing and Analysis of data}

In this research, a researcher considers the sources of data in both primary and secondary data for completing research objectives. A letter requesting permission to collect data from Consumer goods industries management was delivered.

Enough time to respond is given to the respondents and they are assured about the confidentiality of responses provided, as it is for research purposes. After data collection from Consumer goods industries staff, the data Processing follows tallying the respondent's answers from the questionnaire through editing, coding, recording, classifying and makes the tabulation of data collected.

\section{i. Editing}

According to Roth [77] editing is a process of re-evaluation and collection of errors either by judgment or fact. It also involves correction of spelling, punctuations or capitalization. Editing has been used to cross-examine the relationship with findings.

\section{ii. Coding}

The purpose of this is to make the precise manageable data, classifying information and putting them in an understandable language. The responses are put into limited number of categories and classes that are appropriate to the research problem.

\section{iii. Classification}

Due to information got from different respondents, the data have been classified in different groups, according to age, sex, and occupation, to make it easy for analysis and interpretation of data.

\section{iv. Tabulation}

After editing of data obtain, the use of statistical tables are applicable by showing the number of the responses to particular questions.

\section{Interpretation}

Interpretation as the central intellectual operation in research, the researcher revealed to potential followers and critics alike the why, the how, and what form of interpretive methods. The methods are used to analyze the data in this research are descriptive Statistics methods which describe the components of WC and describing also the profitability factors of consumer goods industries. It is in this regard descriptive statistics are used such as frequency, percentages, and cumulative percentage. The correlation coefficient is calculated to show the influence of WCM on profitability of Consumer goods industries in Rwanda.

Table-3: Interpretation of Pearson Correlation Legend

\begin{tabular}{|l|l|l|}
\hline 1. & $\rho=1$ & Perfect Correlation \\
\hline 2. & $0.9 \leq \mathrm{p}<1$ & Strong Correlation (Very High) \\
\hline 3. & $0.7 \leq \mathrm{p}<0.9$ & High Correlation \\
\hline 4. & $0.5 \leq \mathrm{p}<0.7$ & Moderate Correlation \\
\hline 5. & $\mathrm{p}<0.5$ & Weak (Low) Correlation \\
\hline 6. & $\mathrm{p}=0$ & Absence of Correlation \\
\hline
\end{tabular}

\section{Quantitative Analysis}

The research model was derived from the theoretical framework of theory of trading policies. This hypothesized there is a direct and positive association between working capital management and profitability of consumer goods industries in Rwanda. The relationship among the variable is depicted below. The equation for profitability of Consumer goods industries is expressed in the following equation:

$\mathbf{Y s}=\beta_{0}+\beta_{1} X_{1}+\beta_{2} X_{2}+\beta_{3} X_{3}+£$,

$\mathbf{Y s}=$ profitability of consumer goods industries

$\boldsymbol{\beta}_{\mathbf{0}}=$ constant (coefficient of intercept)

$\mathbf{X}_{\mathbf{1}}=$ Inventory management

$\mathbf{X}_{\mathbf{2}}=$ Cash management

$\mathbf{X}_{\mathbf{3}}=$ Account receivable and payable management

B1 ... B3 = regression coefficient of four variables. 
Inferential statistics such non-parametric test which include analysis of variance (ANOVA) were used to test the significance of the overall model at $95 \%$ level of significance. According to Mugenda [78] analysis of variance is used because it makes use of the F-test in terms of sums of squares residual.

The chi-square was used to measure association between Inventory management, Cash management, Account receivable and payable management and profitability of Consumer goods industries in Rwanda.

\section{DATA PRESENTATION， ANALYSIS, INTERPRETATION \\ Analysis of Data}

The questionnaires were distributed to the 59 of respondents' employees of consumer goods industries included by BRALIRWA Plc, INYANGE Industry, SKOL Brewery, and Enterprise Urwibutso.
The respondents were given three days of responding to the questionnaire. During collection of answered questionnaires, the researcher found the participation rate was $100.0 \%$ of responding. However, analysis done on data to the socio-characteristics of respondents; the findings on the effect of Inventory management on the profitability of consumer goods industries; the effective cash management on the profitability of consumer goods industries; and the influence of Account receivable/payable management on the profitability of consumer goods industry.

\section{Analysis of Socio-Demographic Characteristic of Respondents}

The socio-demographic characteristic of the respondents shows information on gender, education level, marital status, and working experience in consumer goods industry. The Table-4 illustrates the findings on social demographic characteristics of respondents as follows.

Table-4: Socio-Demographic Characteristics of Respondents

\begin{tabular}{|l|l|l|l|}
\hline \multirow{3}{*}{ Gender Balance } & Data & Frequency & Percentages \\
\hline \multirow{4}{*}{ Ages of Respondents } & Male & 31 & 52.5 \\
\cline { 2 - 4 } & Female & 28 & 47.5 \\
\cline { 2 - 4 } & Between 21 and 30 years & 27 & 45.8 \\
\cline { 2 - 4 } & 31 and 40 years & 12 & 20.3 \\
\cline { 2 - 4 } & Between 41 and 50 years & 13 & 22.0 \\
\cline { 2 - 4 } & 51 years and above & 7 & 11.9 \\
\hline \multirow{3}{*}{ Level of education } & Masters' Degree & 8 & 13.6 \\
\cline { 2 - 4 } & Bachelor's' Degree & 51 & 86.5 \\
\hline & Single & 17 & 28.8 \\
\cline { 2 - 4 } & Married & 42 & 71.2 \\
\cline { 2 - 4 } & Total & $\mathbf{5 9}$ & $\mathbf{1 0 0 . 0}$ \\
\hline
\end{tabular}

Source: Primary Data, September (2018)

The findings presented on the Table-4 shows information on the socio-demographic characteristics of respondents from selected consumer goods industries in Rwanda included by Bralirwa, Skol, Inyange, and Urwibutso enterprise.

\section{Analysis of Working Capital Management on the Profitability of Consumer goods industries}

During this study at consumer goods industries, the results show the answers on how does operating Cycle influence the Profitability of consumer goods industry? How does Inventory management affect the Profitability of consumer goods industry? How is effective of cash management on the profitability of consumer goods industry? How does Account Receivable Management contribute to profitability of consumer goods industries?
The Effect of Inventory Management on the Profitability of Consumer goods industries

The effect of Inventory management in Consumer goods industries is to make sure that every product needed to be sold on market is available in stock; Consumer goods industries has no extra material that can get spoiled because are not used or sold as proper inventory Management; the store room is well maintained in order to keep well goods, every material is well coded in the book of record of consumer goods industry, every material does what it is supposed to do in order to facilitate future production, inventory is well kept for generating high income, expenses are reduced because of the due care given to inventory as result to generate revenue, profit keeps increasing because of the due care given to inventory management at Consumer goods industries, and dividends keep increasing because of the due care given to inventory of products. Table- 5 presents the effect of Inventory management on the profitability of consumer goods industries as follows. 
Table-5: The effect of Inventory management on the Profitability of Consumer Goods Industries

\begin{tabular}{|c|c|c|c|c|c|c|c|c|}
\hline \multirow[t]{2}{*}{ The effect of Inventory management } & \multicolumn{2}{|l|}{ SA } & \multicolumn{2}{|l|}{$\mathbf{A}$} & \multicolumn{2}{|l|}{ D } & \multicolumn{2}{|c|}{ SD } \\
\hline & fi & $\%$ & fi & $\%$ & fi & $\%$ & fi & $\%$ \\
\hline $\begin{array}{l}\text { In consumer goods industry, they make sure that every product } \\
\text { needed to be sold on market is available in stock }\end{array}$ & 26 & 44.1 & 29 & 49.2 & 4 & 6.8 & 0 & 0.0 \\
\hline $\begin{array}{l}\text { Consumer goods industries had no extra material that can get } \\
\text { spoiled because are not used or sold as proper Inventory } \\
\text { Management }\end{array}$ & 30 & 50.8 & 26 & 44.1 & 3 & 5.1 & 0 & 0.0 \\
\hline The store room is well maintained in order to keep well goods & 36 & 61.0 & 19 & 32.2 & 2 & 3.4 & 2 & 3.4 \\
\hline $\begin{array}{l}\text { Every material is well coded in the book of record of consumer } \\
\text { goods industry }\end{array}$ & 33 & 55.9 & 25 & 42.4 & 1 & 1.7 & 0 & 0.0 \\
\hline $\begin{array}{l}\text { Every material does what it is supposed to do in order to facilitate } \\
\text { future production }\end{array}$ & 40 & 67.8 & 17 & 28.8 & 1 & 1.7 & 1 & 1.7 \\
\hline Inventory is well kept for generating high income & 33 & 55.9 & 26 & 44.1 & 0 & 0.0 & 0 & 0.0 \\
\hline $\begin{array}{l}\text { Expenses are reduced because of the due care given to inventory as } \\
\text { result to generate revenue }\end{array}$ & 26 & 44.1 & 27 & 45.8 & 2 & 3.4 & 4 & 6.8 \\
\hline $\begin{array}{l}\text { Profit keeps increasing because of the due care given to inventory } \\
\text { management at consumer goods industry }\end{array}$ & 34 & 57.6 & 22 & 37.3 & 1 & 1.7 & 2 & 3.4 \\
\hline $\begin{array}{l}\text { Dividends keep increasing because of the due care given to } \\
\text { inventory of products }\end{array}$ & 26 & 44.1 & 31 & 52.5 & 2 & 3.4 & 0 & 0.0 \\
\hline
\end{tabular}

Source: Primary Data, September (2018)

This Table-5 presents the perceptions of respondents on the effect of Inventory management on the profitability of consumer goods industries

\section{The effectiveness of Cash Management on the Profitability of Consumer goods industries \\ The study conducted at Consumer goods} industries on the effective of cash management on the profitability of Consumer goods industries show that petty cash in consumer goods industries is always available for solving little payments, cash are always disbursed after being approved by official workers, cash are always disbursed according to the budget, cash to be disbursed is always supported by reliable documents, this company keeps itself regularly liquid, duties for cash management are well segregated, and none can steal money, expenses are reduced because of the due care given to the cash, profit keeps increasing because of the due care given to the cash, dividends keep increasing because of the due care given to the cash, and all bills are paid on time at Consumer goods industries as table 6 presents the information from respondents as follows.

Table-6: The effectiveness of cash management on the Profitability of consumer goods industries

\begin{tabular}{|c|c|c|c|c|c|c|c|c|}
\hline \multirow[t]{2}{*}{ Effective cash management } & \multicolumn{2}{|l|}{$\mathbf{S A}$} & \multicolumn{2}{|l|}{$\mathbf{A}$} & \multicolumn{2}{|l|}{$\mathbf{D}$} & \multicolumn{2}{|c|}{ SD } \\
\hline & fi & $\%$ & fi & $\%$ & fi & $\%$ & fi & $\%$ \\
\hline iilable for solving little payments & 29 & 49.2 & 28 & 47.5 & 2 & 3.4 & 0 & 0.0 \\
\hline Cash are always disbursed after being approved by officia & 34 & 57.6 & 21 & 35.6 & 2 & 3.4 & 2 & 3.4 \\
\hline Cash are always disbursed according to the budget & 31 & 52.5 & 27 & 45.8 & 1 & 1.7 & 0 & 0.0 \\
\hline ursed is always supported by reliable & 27 & 45.8 & 31 & 52.5 & 0 & 0.0 & 1 & 1.7 \\
\hline gularly liquid & 30 & 50.8 & 28 & 47.5 & 1 & 1.7 & 0 & 0.0 \\
\hline $\begin{array}{l}\text { Duties for cash management are well segregated, and none can steal } \\
\text { money }\end{array}$ & 37 & 62.7 & 17 & 28.8 & 3 & 5.1 & 2 & 3.4 \\
\hline s are reduced because of the due care given to the cash & 36 & 61.0 & 20 & 33.9 & 1 & 1.7 & 1 & 1.7 \\
\hline ps increasing because of the due care given to the cash & 32 & 54.2 & 25 & 42.4 & 1 & 1.7 & 1 & 1.7 \\
\hline Dividends keep incre & 29 & 49.2 & 29 & 49.2 & 1 & 1.7 & 0 & 0.0 \\
\hline All bills are paid on time at consumer goods industry & 38 & 64.4 & 15 & 25.4 & 4 & 6.8 & 2 & 3.4 \\
\hline
\end{tabular}

Source: Primary Data, September (2018)

The Table-6 presents the information from respondents on the effectiveness of cash management on the Profitability of consumer goods industries.

\section{Analysis of Account Receivable Management on the Profitability of Consumer goods industries \\ Account receivable management influences the profitability of Consumer goods industries where a debt}

is only given after assessing the capacity of the purchaser to repay the debt; there is a good policy of paying the debt; receivable management policy is well implemented; no one is given a debt without making promises of how s/he pays it; a debt is only given by an employee who has this right; this company has a good system of remind people about the debt they have and encourage them to pay when it is necessary; receivables 
are well filed; liabilities are paid on time in order not to be charged; liabilities are regularly paid from receivables; this company make sure that liabilities are well filed; and consumer goods industries makes as much as possible so that current liabilities be at least a half of the current assets. The Table-7 illustrates the perceptions of respondents on the account receivable management on the profitability of consumer goods industries.

Table-7: Analysis on the Account Receivable/payable Management on the Profitability of consumer goods industries

\begin{tabular}{|c|c|c|c|c|c|c|c|c|}
\hline \multirow[t]{2}{*}{ Account Receivable Management } & \multicolumn{2}{|l|}{ SA } & \multicolumn{2}{|l|}{$\mathbf{A}$} & \multicolumn{2}{|l|}{ D } & \multicolumn{2}{|c|}{ SD } \\
\hline & fi & $\%$ & fi & $\%$ & fi & $\%$ & fi & $\%$ \\
\hline $\begin{array}{l}\text { A debt is only given after assessing the capacity of the purchaser to } \\
\text { repay the debt }\end{array}$ & 34 & 57.6 & 18 & 30.5 & 2 & 3.4 & 5 & 8.5 \\
\hline There is a good policy of paying the debt & 33 & 55.9 & 18 & 30.5 & 4 & 6.8 & 4 & 6.8 \\
\hline Receivable management policy is well implemented & 20 & 33.9 & 35 & 59.3 & 2 & 3.4 & 2 & 3.4 \\
\hline $\begin{array}{l}\text { No one is given a debt without making promises of how he will pay } \\
\text { it }\end{array}$ & 20 & 33.9 & 36 & 61.0 & 3 & 5.1 & 0 & 0.0 \\
\hline A debt is only given by an employee who has this right & 35 & 59.3 & 20 & 33.9 & 1 & 1.7 & 3 & 5.1 \\
\hline $\begin{array}{l}\text { This company has a good system of remind people about the debt } \\
\text { they have and encourage them to pay when it is necessary }\end{array}$ & 23 & 39.0 & 30 & 50.8 & 3 & 5.1 & 3 & 5.1 \\
\hline Receivables are well filed & 19 & 32.2 & 38 & 64.4 & 1 & 1.7 & 1 & 1.7 \\
\hline Liabilities are paid on time in order not to be charged & 28 & 47.5 & 25 & 42.4 & 3 & 5.1 & 3 & 5.1 \\
\hline Liabilities are regularly paid from receivables & 34 & 57.6 & 22 & 37.3 & 1 & 1.7 & 2 & 3.4 \\
\hline Consumer goods industries makes sure that liabilities are well filed & 26 & 44.1 & 31 & 52.5 & 0 & 0.0 & 2 & 3.4 \\
\hline $\begin{array}{l}\text { Consumer goods industries makes as much as possible so that } \\
\text { current liabilities be at least a half of the current assets }\end{array}$ & 29 & 49.2 & 28 & 47.5 & 2 & 3.4 & 0 & 0.0 \\
\hline
\end{tabular}

Source: Primary Data, September (2018)

The table-7 illustrates the perceptions of respondents on the account receivable management on the profitability of consumer goods industries.

\section{Correlation Coefficient Test}

This part concentrates on analysis of how Working Capital Management contributes to profitability of consumer goods industries in Rwanda.
All responses related to the questions on Working Capital Management were summarized to generate a representative independent variable while all responses related to performance of Consumer goods industries were totaled to give the dependent variable. In correlating using Spearman analysis the research got table below:

Table-8: Correlation Coefficient Test

\begin{tabular}{|l|l|l|l|l|}
\hline \multirow{4}{*}{ Spearman's rho } & \multirow{2}{*}{$\begin{array}{l}\text { Working capital } \\
\text { management }\end{array}$} & $\begin{array}{l}\text { Correlation } \\
\text { Coefficient }\end{array}$ & 1.000 & $.758^{* *}$ \\
\cline { 3 - 5 } & Sig. (2-tailed) &. & .000 \\
\cline { 3 - 5 } & $\mathrm{N}$ & 59 & 59 \\
\cline { 2 - 5 } & Profitability & $\begin{array}{l}\text { Correlation } \\
\text { Coefficient }\end{array}$ & $.758^{* *}$ & 1.000 \\
\cline { 3 - 5 } & Sig. (2-tailed) & .000 & 6 \\
\cline { 2 - 5 } & $\mathrm{N}$ & 59 & 60 \\
\hline
\end{tabular}

\section{Linear Regression analysis}

During this study, a linear regression line is used as an equation of the form $\mathrm{Y}=\mathrm{a}+\mathrm{bX}$, where $\mathrm{X}$ is the explanatory variable and $\mathrm{Y}$ is the dependent variable. The slope of the line is $b$, and a is the intercept (the value of $\mathrm{y}$ when $\mathrm{x}=0$ ). The models show the linear relationship between the dependent variable which is profitability (NPM, GPM, ROA, and ROE) of consumer goods industries and working capital management as independent variable which are inventory, cash, and account receivable/payable management. 
Table-9: Model of NPM

\begin{tabular}{|l|l|l|l|l|}
\hline \multicolumn{4}{|c|}{ Model Summary } \\
\hline Model & R & R Square & Adjusted R Square & Std. Error of the Estimate \\
\hline 1 & $.814^{\mathrm{a}}$ & .662 & .211 & .10545 \\
\hline \multicolumn{4}{|l|}{ a. Predictors: (Constant), Inventory conversion Period, Average Collection Period, Average Payment Period } \\
\hline
\end{tabular}

Table-10: Model of GPM

\begin{tabular}{|l|l|l|l|l|}
\hline \multicolumn{4}{|c|}{ Model Summary } \\
\hline Model & R & R Square & Adjusted R Square & Std. Error of the Estimate \\
\hline 1 & $.922^{\mathrm{a}}$ & .849 & .649 & .05828 \\
\hline a. Predictors: (Constant), inventory, cash, and account receivable/payable management \\
\hline
\end{tabular}

Table-11: ANOVA for NPM

\begin{tabular}{|c|c|c|c|c|c|c|}
\hline \multicolumn{7}{|c|}{ ANOVA $^{\mathrm{a}}$} \\
\hline \multicolumn{2}{|c|}{ Model } & Sum of Squares & df & Mean Square & $\mathrm{F}$ & Sig. \\
\hline \multirow[t]{3}{*}{1} & Regression & .058 & 4 & .014 & 4.233 & $.033^{\mathrm{b}}$ \\
\hline & Residual & .010 & 3 & .003 & & \\
\hline & Total & .068 & 7 & & & \\
\hline \multicolumn{7}{|c|}{ a. Dependent Variable: Net Profit Margin } \\
\hline
\end{tabular}

The Table-11 indicates there was positive gradient which reveals that an effective working capital management led to increased profitability of Consumer goods industries in Rwanda

Table-12: ANOVA for GPM

\begin{tabular}{|l|l|l|l|l|l|l|}
\hline \multicolumn{7}{|c|}{ ANOVA $^{\text {a }}$} \\
\hline \multicolumn{2}{|l|}{ Model } & Sum of Squares & df & Mean Square & F & Sig. \\
\hline \multirow{3}{*}{1} & Regression & .065 & 4 & .016 & 1.469 & $.039^{\mathrm{b}}$ \\
\cline { 2 - 7 } & Residual & .033 & 3 & .011 & & \\
\cline { 2 - 5 } & Total & .099 & 7 & & & \\
\hline
\end{tabular}

a. Dependent Variable: Gross Profit Margin

b. Predictors: (Constant), inventory, cash, and account receivable/payable management

Table-13: Coefficients for NPM

\begin{tabular}{|c|c|c|c|c|c|c|}
\hline \multicolumn{7}{|c|}{ Coefficients $^{\mathrm{a}}$} \\
\hline \multirow[t]{2}{*}{ Model } & \multicolumn{2}{|l|}{ Unstandardized Coefficients } & \multirow{2}{*}{\multicolumn{2}{|c|}{$\begin{array}{l}\text { Standardized Coefficients } \\
\text { Beta }\end{array}$}} & \multirow[t]{2}{*}{$\mathrm{t}$} & \multirow[t]{2}{*}{ Sig. } \\
\hline & $\mathrm{B}$ & Std. Error & & & & \\
\hline \multirow[t]{5}{*}{1} & (Constant) & -.460 & 1.263 & & -.364 & .740 \\
\hline & Inventory conversion Period & .002 & .002 & .638 & 1.092 & .355 \\
\hline & Average Collection Period & .002 & .013 & .198 & .160 & .883 \\
\hline & Average Payment Period & .000 & .011 & .105 & .043 & .969 \\
\hline & & .002 & .005 & .615 & .359 & .743 \\
\hline
\end{tabular}

$\mathrm{NPM}=-.460+.002 \mathrm{ICP}+.002 \mathrm{ACP}+.000 \mathrm{APP}+£$

Table-14: Coefficients for GPM

\begin{tabular}{|l|l|l|l|l|l|l|}
\hline \multicolumn{9}{|c|}{ Coefficients } \\
\hline \multirow{3}{*}{ Model } & Unstandardized Coefficients & Standardized Coefficients & \multicolumn{2}{l|}{ Sig. } \\
\cline { 2 - 8 } & B & Std. Error & Beta & & & \\
\hline \multirow{1}{*}{1} & Constant) & -.365 & 2.285 & & -.160 & .883 \\
\cline { 2 - 8 } & Inventory conversion Period & .003 & .004 & .639 & .729 & .519 \\
\cline { 2 - 8 } & Average Collection Period & .002 & .024 & .151 & .081 & .940 \\
\cline { 2 - 8 } & Average Payment Period & .001 & .020 & .213 & .057 & .958 \\
\cline { 2 - 8 } & & .002 & .010 & .548 & .213 & .845 \\
\hline
\end{tabular}

a. Dependent Variable: Gross Profit Margin

$$
\mathrm{GPM}=-.365+.003 \mathrm{ICP}+.002 \mathrm{ACP}+.001 \mathrm{APP}+£
$$




\section{Overall regression analysis}

The study uses linear regression by analyzing the working capital management in terms of "inventory management; cash management; and account receivable/ payable management" as independent variable, with profitability in terms of "ROA, ROE, GPM, and NPM" as dependent variable. The study used the formula of $\mathbf{Y}=\beta_{0}+\beta_{1} X_{1}+\beta_{2} X_{2}+\beta_{3} X_{3+} \varepsilon . \quad \mathbf{Y}$ is dependent variable indicator which is "profitability". $\mathbf{X}$ is independent variable which shows the elements of WCM where $\mathrm{X}_{1}$ represent inventory management, $\mathrm{X}_{2}$ is cash management, and $\mathrm{X}_{3}$ is account receivable management.

Table-15: Coefficients

\begin{tabular}{|c|c|c|c|c|c|c|}
\hline \multirow{2}{*}{\multicolumn{2}{|c|}{ Model }} & \multicolumn{2}{|c|}{$\begin{array}{l}\text { Unstandardized } \\
\text { Coefficients }\end{array}$} & \multirow{3}{*}{$\begin{array}{l}\text { Standardized } \\
\text { Coefficients } \\
\text { Beta }\end{array}$} & \multirow[t]{2}{*}{$\mathrm{t}$} & \multirow[t]{2}{*}{ Sig. } \\
\hline & & \multirow{2}{*}{$\begin{array}{l}\mathrm{B} \\
1.176 \\
\end{array}$} & \multirow{2}{*}{$\begin{array}{l}\text { Std. Error } \\
.680\end{array}$} & & & \\
\hline 1 & (Constant) & & & & 1.730 & .089 \\
\hline & Inventory Management & .204 & .206 & .133 & -.992 & .326 \\
\hline & Cash Management & .072 & .168 & .061 & .431 & .168 \\
\hline & Account Receivable/payable & .403 & .261 & .211 & 1.544 & .128 \\
\hline
\end{tabular}

a. Dependent Variable: Profitability

\section{Profitability Analysis Ratios of Consumer goods Industries}

Common profitability ratios used by consumer goods industries included by ROA, ROE, GPM, and NPM as table below shows more about profitability analysis ratios since 2013 to 2017 .

Table-16: GPM Ratios of Consumer goods Industries

\begin{tabular}{|l|l|l|l|l|l|}
\hline & $\mathbf{2 0 1 3}$ & $\mathbf{2 0 1 4}$ & $\mathbf{2 0 1 5}$ & $\mathbf{2 0 1 6}$ & $\mathbf{2 0 1 7}$ \\
\hline BRALIRWA Plc & $40.55 \%$ & $36.88 \%$ & $31.12 \%$ & $28.91 \%$ & $30,42 \%$ \\
\hline INYANGE Industry & $41.62 \%$ & $41.90 \%$ & $44.94 \%$ & $45.82 \%$ & $50.11 \%$ \\
\hline SKOL Brewery & $77 \%$ & $59 \%$ & $53 \%$ & $32 \%$ & $64 \%$ \\
\hline Enterprise Urwibutso & $99,83 \%$ & $87,12 \%$ & $94,33 \%$ & $112,26 \%$ & $114,56 \%$ \\
\hline
\end{tabular}

Source: Secondary data, annually financial report (2017)

GPM was $40.55 \%$ in $2013 ; 36.88 \%$ in 2014 ; $31.12 \%$ in $2015 ; 28.91 \%$ in 2016 while $30,42 \%$ became the GPM of 2017 in BRALIRWA Plc. INYANGE Industry in 2013 was $41.62 \%$ increased clearly in 2014 until $41.90 \%$ and in 2015, Gross profit Margin was $44.94 \%$. The year 2016, GPM was $45.82 \%$ while in 2017, GPM was $50.11 \%$. SKOL Industry had GPM of
$77 \%$ in 2013, while in 2014, GPM was $59 \%$ in SKOL, in 2015 , GPM was $53 \%$, in 2016 GPM was $32 \%$ while in 2017, GPM was 64\% in SKOL Industry. At Enterprise Urwibutso, in 2013, GPM was $99,83 \%$; in 2014 , it was becoming $87,12 \%$; GPM was $94,33 \%$ in 2015 while in 2016, it was $112,26 \%$ and GPM of Enterprise Urwibutso became 114,56\% in 2017.

Table-17: NPM Ratios of Consumer goods Industries

\begin{tabular}{|l|l|l|l|l|l|}
\hline & $\mathbf{2 0 1 3}$ & $\mathbf{2 0 1 4}$ & $\mathbf{2 0 1 5}$ & $\mathbf{2 0 1 6}$ & $\mathbf{2 0 1 7}$ \\
\hline BRALIRWA Plc & $19.69 \%$ & $16.71 \%$ & $8.45 \%$ & $1.57 \%$ & $5,88 \%$ \\
\hline INYANGE Industry & $33.89 \%$ & $33.13 \%$ & $36.17 \%$ & $36.46 \%$ & $43.81 \%$ \\
\hline SKOL Brewery & $14,90 \%$ & $5,16 \%$ & $1,953 \%$ & $11,03 \%$ & $21,01 \%$ \\
\hline Enterprise Urwibutso & $2,37 \%$ & $2,93 \%$ & $3,23 \%$ & $15,93 \%$ & $6,85 \%$ \\
\hline
\end{tabular}

Source: Secondary data, annually financial report (2017)

The NP\% was $19.69 \%$ in the year 2013 while in 2014 was $16.71 \%$; in 2015 , NPM was $8.45 \%$; in 2016 , it was $1.57 \%$ while in the year 2017, NPM was $5,88 \%$ in BRALIRWA Plc. The net profit ratio of INYANGE Industry in 2013 is $33.89 \% \%$; in 2014 net profit increased on $33.13 \% \%$; in 2015, NPM was $36.17 \%$; in 2016, NPM was $36.46 \%$; and in 2017, NPM was $43.81 \%$. SKOL Industry, in 2013, GMP was
$14,90 \%$, in 2014 was $5,16 \%$, in 2015 , NPM was $1,953 \%$, in 2016 was $11,03 \%$, and in 2017 NPM was $21,01 \%$ in SKOL Company. The net profit ratio of Enterprise Urwibutso in 2013, it was 2,37\%; net profit was $2,93 \%$ in 2014 ; while in 2015 , NPM was $3,23 \%$; in 2016, NPM was $15,93 \%$ and in 2017 , NPM was $6,85 \%$ at Enterprise Urwibutso. 
Table-18: ROA Ratios of Consumer goods Industries

\begin{tabular}{|l|l|l|l|l|l|}
\hline & $\mathbf{2 0 1 3}$ & $\mathbf{2 0 1 4}$ & $\mathbf{2 0 1 5}$ & $\mathbf{2 0 1 6}$ & $\mathbf{2 0 1 7}$ \\
\hline BRALIRWA Plc & $16.88 \%$ & $12.35 \%$ & $5.78 \%$ & $1.06 \%$ & $3,97 \%$ \\
\hline INYANGE Industry & $3.64 \%$ & $3.51 \%$ & $3.79 \%$ & $3.64 \%$ & $4.10 \%$ \\
\hline SKOL Brewery & $12,26 \%$ & $50,82 \%$ & $15.00 \%$ & $9.17 \%$ & $8,68 \%$ \\
\hline Enterprise Urwibutso & $0,55 \%$ & $0,70 \%$ & $0,74 \%$ & $3,67 \%$ & $1,52 \%$ \\
\hline
\end{tabular}

Source: Secondary data, annually financial report (2017)

ROA was $16.88 \%$ in 2013 , while in 2014 , it was $12.35 \%$; in 2015 ROA was $5.78 \%$; it was $1.06 \%$ while in 2017, ROA was 3,97\% in BRALIRWA Plc. Return on Asset of INYANGE Industry was in 2013 was $3.64 \%$, in 2014 ; return on asset was $3.51 \%$, in 2015 , ROA was $3.79 \%$ while the year of 2016 , ROA was $3.64 \%$ and in 2017, ROA was $4.10 \%$. SKOL
Industry in 2013 had ROA of $138,35 \%$, in 2014 ROE was $65.04 \%$, in 2015 was $18.95 \%$, in 2016 ROA was $104,56 \%$ while in 2017 , ROA was $12,54 \%$. Return on Asset of Enterprise Urwibutso was in 2013 was 0,55\%; in 2014; return on asset was $30,70 \%$; in 2015 , ROA was $0,74 \%$; while the year of 2016 , ROA was $3,67 \%$; and in 2017, ROA was 1,52\% at Enterprise Urwibutso.

Table-19: ROE Ratios of Consumer goods Industries

\begin{tabular}{|l|l|l|l|l|l|}
\hline & $\mathbf{2 0 1 3}$ & $\mathbf{2 0 1 4}$ & $\mathbf{2 0 1 5}$ & $\mathbf{2 0 1 6}$ & $\mathbf{2 0 1 7}$ \\
\hline BRALIRWA Plc & $43.93 \%$ & $32.52 \%$ & $20.08 \%$ & $4.41 \%$ & $14,22 \%$ \\
\hline INYANGE Industry & $18.66 \%$ & $20.95 \%$ & $20.45 \%$ & $20.63 \%$ & $24.16 \%$ \\
\hline SKOL Brewery & $138,35 \%$ & $65,04 \%$ & $18,95 \%$ & $104,56 \%$ & $12,54 \%$ \\
\hline Enterprise Urwibutso & $2,34 \%$ & $3,21 \%$ & $3,52 \%$ & $17,93 \%$ & $6,90 \%$ \\
\hline
\end{tabular}

Source: Secondary data, annually financial report (2017)

ROE was also $43.93 \%$ in the year of 2013 while in 2014 was becoming $32.52 \%$; in 2015 ROE was $20.08 \%$; in 2016 it was $4.41 \%$ while in 2017 , ROE was becoming $14,22 \%$ in BRALIRWA Plc. ROE of INYANGE was in 2013 became $18.66 \%$, while in 2014 was became $20.95 \%$ and in 2015 became $20.45 \%$, and in 2016 , ROE was $20.63 \%$ while in 2017 , ROE was $24.16 \%$. SKOL Industry in 2013 , ROE was $14,90 \%$, in 2014 was $5,16 \%$, in 2015, NPM was $1,953 \%$, in 2016 was $11,03 \%$, and in $2017 \mathrm{NPM}$ was $21,01 \%$. ROE of Enterprise Urwibutso was in 2013 became 2,34\%; in 2014 ROE was 3,21\%; in 2015 became 3,52\%; and in 2016, ROE was $17,93 \%$ while in 2017 , ROE was $6,90 \%$.

\section{Interpretation and presentation of the Findings}

The findings presented on the table 4 shows information on the socio-demographic characteristics of respondents from consumer goods industry. In gender balance, $52.5 \%$ of respondents were males, while $47.5 \%$ of respondents were females. Consumer goods industries respects Rwandan gender law which expected to be $30 \%$ of female in the organization employment opportunity. In regard to the ages of respondents, $45.8 \%$ of respondents have the ages from 21 to 30 years. $20.3 \%$ of respondents were between 31 and 40 years old. The range between 41 and 50 years old were $22.0 \%$ of respondents. $11.9 \%$ of respondents have 51 years and above. Consumer goods industries employ majority of $45.8 \%$ respondents who are mature and active to generate profit for company. During this study at consumer goods industries, there is no illiterate employee met within this company where $86.5 \%$ respondents had Bachelors' Degree, while 13.6\% of respondents had master's degree. Consumer goods industries employed the qualified employees as factor could lead to the achievement of profitability. Marital status of respondents was shown by $28.8 \%$ of respondents who were the single, and $71.2 \%$ of respondents who were married. Majority of respondents were married category of employee was stable to work within organization.

\section{Findings on Inventory management and Profitability of consumer goods industries}

Table-5 presents the perceptions of respondents on the effect of Inventory management on the profitability of consumer goods industry. In consumer goods industry, they make sure that every product needed to be sold on market is available in stock was confirmed on rate of $93.2 \%$ of respondents. Consumer goods industries has no extra material that can get spoiled because are not used or sold as proper Inventory Management as confirmed by $94.9 \%$ of respondents. The store room is well maintained in order to keep well goods was confirmed by $93.2 \%$ of respondents. Every material is well coded in the book of record of Consumer goods industries was confirmed by 98.3\%. Every material does what it is supposed to do in order to facilitate future production was confirmed by $96.6 \%$ of respondents in consumer goods industry. Inventory is well kept for generating high income was confirmed by $100.0 \%$ respondents. Expenses are reduced because of the due care given to inventory as result to generate revenue was on rate of $89.8 \%$. Profit keeps increasing because of the due care given to inventory management at Consumer goods industries was confirmed by $94.9 \%$ of respondents. Dividends keep increasing because of the due care given to inventory of products was on rate of $96.6 \%$ respondents from consumer goods industry. 
The results indicated above supported by the study of Brealey et al., [51] who found that a large amount of companies did significantly reduce their inventory levels. This reduction was mostly implemented on the levels of work-in-progress inventory. Inventory or stocks are goods held for sale or for processing end products, and are a crucial make-up of current assets where Consumer goods industries have no extra material that can get spoiled because are not used or sold as proper Inventory Management, the store room is well maintained in order to keep well goods, every material is well coded in the book of record of consumer goods industry, it is supposed to do in order to facilitate future production, Inventory is well kept for generating high income, Expenses are reduced because of the due care given to inventory as result to generate revenue, Profit keeps increasing because of the due care given to inventory management at consumer goods industry, and dividends keep increasing because of the due care given to inventory of products. Inventory in manufacturing firms are in the form of raw materials, works in progress and finished goods. In most cases, it is a balancing act to keep inventory for sales and having less inventory to improve working capital. A concept that has originated from Japan for managing inventory is just-in-time (JIT). The just-in-time keeps suppliers ready to supply goods or stocks when the need arises to satisfy customer demand. By this way, inventories are held at zero or in low levels.

\section{Findings on the effective cash management on the Profitability of Consumer goods industries}

Table-6 presents the information from respondents on the effective of cash management on the Profitability of consumer goods industry. The petty cash is always available for solving little payments was confirmed by $96.6 \%$ of respondents. Cash are always disbursed after being approved by official workers was confirmed by $93.2 \%$ of respondents. Cash are always disbursed according to the budget was on rate of $98.3 \%$ of respondents of consumer goods industry. Cash to be disbursed is always supported by reliable documents was confirmed by $98.3 \%$ of respondents. This company keeps itself regularly liquid was confirmed by $98.3 \%$ of respondents. Duties for cash management are well segregated, and none can steal money was confirmed by $91.5 \%$ of respondents. Profit keeps increasing because of the due care given to the cash was confirmed by 96.6\% of respondents. Dividends keep increasing because of the due care given to the cash was confirmed by $98.3 \%$ of respondents of consumer goods industry. All bills are paid on time at Consumer goods industries was confirmed by $89.8 \%$ of respondents.

According to Omesa et al., [78] who examined
the relationships between Working Capital
Management and Corporate Performance of
manufacturing firms listed on the Nairobi securities
exchange. They found out that Petty cash is always
available for solving little payments, Cash are always

disbursed after being approved by official workers, Cash are always disbursed according to the budget, Cash to be disbursed is always supported by reliable documents, company keeps itself regularly liquid, Duties for cash management are well segregated, and none can steal money, Expenses are reduced because of the due care given to the cash, Profit keeps increasing because of the due care given to the cash, and Dividends keep increasing because of the due care given to the cash, working capital proxies; Cash Conversion Cycle, Average Collection Period and control variables Current Liabilities, Net Working Capital Turnover Ratio and Fixed Financial Ratio were significant at $95 \%$ confidence ( $p$ values are < 0.05 ) to performance as measured by Return on Equity (ROE).

\section{Findings on the influences of Account Receivable Management on the profitability of Consumer goods industries}

The Table-7 illustrates the perceptions of respondents on the account receivable management on the profitability of consumer goods industry. A debt is only given after assessing the capacity of the purchaser to repay the debt was confirmed by $88.1 \%$ of respondents of consumer goods industry. There is a good policy of paying the debt in Consumer goods industries as confirmed by $86.4 \%$ of respondents. Receivable management policy is well implemented; this is justified by $93.2 \%$ of respondents from consumer goods industry. No one is given a debt without making promises of how s/he pays it as confirmed by $94.9 \%$ of respondents. A debt is only given by an employee who has this right was confirmed by $93.2 \%$ of respondents.

Consumer goods industries have a good system of remind people about the debt they have and encourage them to pay when it is necessary as more than $89.8 \%$ of respondents confirmed it. Receivables are well filed was confirmed on rate of $96.6 \%$. Liabilities are paid on time in order not to be charged on rate of $89.8 \%$. Liabilities are regularly paid from receivables was confirmed on rate of $94.9 \%$ of respondents. Consumer goods industries make sure that liabilities are well filed as more than $96.6 \%$ of respondents confirmed it. Consumer goods industries makes as much as possible so that current liabilities be at least a half of the current assets was confirmed by $96.6 \%$ of respondents from this manufacturing company.

Gill, B et al., [56] carried out their research between 2005 and 2007. The independent variables were; receivable days, payable days, inventory days, natural logarithm of sales and gearing. They found that debt is only given after assessing the capacity of the purchaser to repay the debt, there is a good policy of paying the debt, Receivable management policy is well implemented, company has a good system of remind people about the debt they have and encourage them to pay when it is necessary, Receivables are well filed, 
Liabilities are paid on time in order not to be charged and regularly paid from receivables, and Consumer goods industries makes sure that liabilities are well filed. They concluded that there is a negative relationship between the profitability and receivable days. Further they also concluded that the relationship between the cash conversion cycle and profitability is positive.

\section{Interpretation of coefficient of determination Results}

The table- 8 shows the P-value which equals to 0.000 which is less than Alpha (0.05). This is an indicator of significant relationship between Working Capital Management and Profitability of Consumer goods industries in Rwanda. The level of significant relationship is 0.758 categorized as high Correlation coefficient with significant level of $0.05(5 \%)$, and the P-Value of $0.000(0 \%)$.

The coefficient of determination $\mathrm{R}^{2}$ shows the degree of association between Variables and Consumer goods industries in Rwanda. The results of the linear regression indicate that $R^{2}=.662$ and $R=.814$ this is an indication that there is a strong relationship between Inventory Conversion Period, Average Collection Period, Average Payment Period, Cash Conversion Cycle and net profit of Consumer goods industries in Rwanda with reference of consumer goods industry.

The coefficient of determination $\mathrm{R}^{2}$ shows the degree of association between the variables and Consumer goods industries in Rwanda. The results of the linear regression indicate that $\mathrm{R}^{2}=.849$ and $\mathrm{R}=.922$ this is an indication that there is a strong relationship between inventory, cash, and account receivable/payable management, and net profit of Consumer goods industries in Rwanda with reference of consumer goods industry.

The Table-12 show the results of ANOVA test which reveal that the working capital management have significant effect on profitability of Consumer goods industries in Rwanda. Since the P value is less than 5\% level of significance. This is depicted by linear regression model, $\mathrm{GPM}=\beta 0+\mathrm{B} 1 \mathrm{X}_{1}+\mathrm{B} 2 \mathrm{X}_{2}+\mathrm{B} 3 \mathrm{X}_{3}+$ $\mathrm{B} 4 \mathrm{X}_{4}+£$, the $\mathrm{P}$ value was 0.039 and 0.03 .

The linear regression test between working capital management and profitability of Consumer goods industries shows the result follows: $y=1.176+0.204 X_{1}+0.072 X_{2}+0.403 X_{3}+\varepsilon$ . However, $X_{1}$ represent inventory management, $X_{2}$ is cash management, $X_{3}$ is account receivable and payable management and lastly, $\varepsilon$ represents standard errors. As explained by the linear regression equation, it is clear that one unit change of $X_{1}, X_{2}$, and $X_{3}$ lead to change times of dependent variable respectively $0.204 ; 0.072$; and 0.403 . In the other case, if all independent variable indicators are zero, the dependent variable equals to the constant (1.176). Thus, according to the result indicated to the table 15 , there is positive relationship between profitability and inventory, cash, and account receivable/payable management as the indicators of working capital management.

The study of Gitman [79] confirmed that Working Capital Management (WCM) presents the Inventory Management, Cash Management, and Account Receivable and it has the objective of minimizing the Cash Conversion Cycle (CCC), that is, the amount of capital tied up in the firm's current assets. It focuses on controlling account receivables and their collection process, and managing the investment in inventory. WCM is vital for all business survival, sustainability and its direct impact on profitability. Working capital management deals with the administration of the liquidity components of firms' short-term current assets and current liabilities

\section{CONCLUSION AND RECOMMENDATIONS CONCLUSIONS}

Working capital management plays a vital role in the profitability of consumer goods industries. It plays key role in cash management, inventory management, account receivable and effective and efficient use of finance. All policies and procedures set down in Consumer goods industries lead to better performance by ensure the reliability of financial information and compliance with laws and regulations. According to the statistics of respondent's answers, working capital helps manufacturing companies to operate efficiently and effectively. Many manufacturing organizations employ some persons and conduct their operations from various departments with many different activities. Then, working capital has to be sound so that there are appropriate control procedures and regulations to be applied in call carrying out all those operations.

Effective and efficient implementations of working capital in manufacturing companies is not the task of one person or one department, it can only be achieved when there is good collaboration and cooperation among all the managers at different levels and with the awareness and full commitment of all employees. That is why each employee should be aware of his/ her role in achievement of goal and objectives of the organization. In addition, establishing all kinds of internal control system in manufacturing companies can also help them to succeed in their operations.

As conclusion, the study findings help to confirm that the problem of this study was solved, research objectives were achieved, research questions were answered and research hypotheses were verified where Null hypothesis was rejected while alternative hypothesis was retained by saying that working capital management influence significantly the profitability of 
Consumer goods industries in Rwanda based to data from consumer goods industries.

\section{RECOMMENDATIONS}

The findings have revealed that working capital management helps to increase profitability of Consumer goods industries in Rwanda.

Therefore, to attain the success for Consumer goods industries must properly follow cash management policies and procedures in Consumer goods industries in order to continue stimulating its profitability.

They should emphasis on good management designed to protect the efficiently and effectively use of finance of consumer goods industries.

Consumer goods industries should ensure the personnel to maintain a level of competence to perform their duties effectively and effective.

\section{REFERENCES}

1. Shin, H. H., \& Soenen, L. (1998). Efficiency of working capital management and corporate profitability. Financial practice and education, 8 , 37-45.

2. Guthman, H. G., \& Dougall, H. E. (1948). Corporate financial policy, 2nd ed. New York, Prentice-Hall Inc.

3. Deloof, M. (2003). Does working capital management affect profitability of Belgian firms?. Journal of business finance \& Accounting, 30(3- 4), 573-588.

4. Lazaridis, I., \& Tryfonidis, D. (2006). Relationship between working capital management and profitability of listed companies in the Athens stock exchange. Journal of financial management and analysis, 19(1).

5. Raheman, A., \& Nasr, M. (2007). Working capital management and profitability-case of Pakistani firms. International review of business research papers, 3(1), 279-300.

6. Shin, J. W., Son, J. Y., Oh, S. M., Han, S. H., Wang, J. H., Cho, J. H., ... \& Hu, X. P. (2006). An herbal formula, CGX, exerts hepatotherapeutic effects on dimethylnitrosamine-induced chronic liver injury model in rats. World Journal of Gastroenterology: WJG, 12(38), 6142.

7. Van, H. J. C., \& Wachowicz, J. M. (2000). Fundamentals of financial management, 11th ed. New York, Prentice Hall Inc.

8. Vishnani, S., \& Shah, B. K. (2007). Impact of Working Capital Management Policies on Corporate Performance: An Empirical Study [Online]. Available from: http://gbr.sagepub.com/cgi/content/abstract

9. Ricci, C., \& Vito, N. (2000). International working capital practices in the UK. European Financial Management, 6(1), 69-84.
10. Rafuse, M. E. (1996). Working capital management: an urgent need to refocus. Management Decision, 34(2), 59-63.

11. Peel, M. J., \& Wilson, N. (1996). Working capital and financial management practices in the small firm sector. International Small Business Journal, 14(2), 52-68.

12. Mateo- Sánchez, M. C., Cushman, S. A., \& Saura, S. (2014). Connecting endangered brown bear subpopulations in the $\mathrm{C}$ antabrian $\mathrm{R}$ ange (north- western $\mathrm{S}$ pain). Animal Conservation, 17(5), 430-440.

13. Masocha, R., \& Dzomonda, O. (2016). The mediating role of effective working capital management on the growth prospects of Small and Medium Enterprises in Polokwane Municipality.

14. Hillier, J. (2010). Strategic navigation in an ocean of theoretical and practice complexity. The Ashgate research companion to planning theory: Conceptual challenges for spatial planning, 447480.

15. Berry, A., \& Jarvis, R. (2006). Accounting in a Business Context, Andover. Cengage Learning EMEA, UK.

16. Sharma, A. K., \& Kumar, S. (2011). Effect of working capital management on firm profitability: Empirical evidence from India. Global business review, 12(1), 159-173.

17. Kargar, J., \& Blumenthal, R. A. (1994). Successful implementation of strategic decisions in small community banks. Journal of Small Business Management, 32(2), 10.

18. Yin, C., \& Fraser, D. C. (2004). Attitude corrections of helicopter EM data using a superposed dipole model. Geophysics, 69(2), 431439.

19. Sartoris, W. L., \& Hill, N. C. (1983). A generalized cash flow approach to short-term financial decisions. The Journal of Finance, 38(2), 349-360.

20. Firth, M. (1976). The impact of earnings announcements on the share price behaviour of similar type firms. The Economic Journal, 86(342), 296-306.

21. Hampton, J. J., Wagner, C. L., \& Cozzini, M. R. (1989). Financial decision making: concepts, problems, and cases. Englewood Cliffs, NJ: Prentice Hall.

22. Leach, J. C., \& Melicher, R. W. (2009). Finance for entrepreneurs. South-Western.

23. Ng, M. K., \& Tang, W. S. (1999). Land- use planning in 'one country, two systems': Hong Kong, Guangzhou and Shenzhen. International Planning Studies, 4(1), 7-27.

24. Lee, Y. W., \& Stowe, J. D. (1993). Product risk, asymmetric information, and trade credit. Journal of Financial and Quantitative analysis, 28(2), 285300 . 
25. Long, M. S., Malitz, I. B., \& Ravid, S. A. (1993). Trade credit, quality guarantees, and product marketability. Financial management, 117-127.

26. Smith, R. L. (1987). Estimating tails of probability distributions. The annals of Statistics, 15(3), 11741207.

27. Emery, G. W., \& Marques, M. A. (2011). The effect of transaction costs, payment terms and power on the level of raw materials inventories. Journal of Operations Management, 29(3), 236-249.

28. Gaur, T., Rich, L., Lengner, C. J., Hussain, S., Trevant, B., Ayers, D., ... \& Lian, J. B. (2006). Secreted frizzled related protein 1 regulates $\mathrm{Wnt}$ signaling for BMP2 induced chondrocyte differentiation. Journal of cellular physiology, 208(1), 87-96.

29. Sack, B., \& Wieland, V. (2000). Interest-rate smoothing and optimal monetary policy: a review of recent empirical evidence. Journal of Economics and Business, 52(1-2), 205-228.

30. Cuthbertson, K., \& Gasparro, D. (1993). The determinants of manufacturing inventories in the UK. The Economic Journal, 103(421), 1479-1492.

31. Lee, G. K., \& Lieberman, M. B. (2010). Acquisition vs. internal development as modes of market entry. Strategic Management Journal, 31(2), 140-158.

32. Cachon, G. P., \& Olivares, M. (2010). Drivers of finished-goods inventory in the US automobile industry. Management science, 56(1), 202-216.

33. Chen, X., Vierling, L., \& Deering, D. (2005). A simple and effective radiometric correction method to improve landscape change detection across sensors and across time. Remote Sensing of Environment, 98(1), 63-79.

34. Rajagopalan, S., \& Malhotra, A. (2001). Have US manufacturing inventories really decreased? An empirical study. Manufacturing \& Service Operations Management, 3(1), 14-24.

35. Blinder, A. S., \& Maccini, L. J. (1990). The resurgence of inventory research: what we have learned?'. NBER Working Paper, (3408).

36. Eichenbaum, M. S. (1984). Rational expectations and the smoothing properties of inventories of finished goods. Journal of Monetary Economics, 14(1), 71-96.

37. Eichenbaum, H., Wiener, S. I., Shapiro, M. L., \& Cohen, N. J. (1989). The organization of spatial coding in the hippocampus: a study of neural ensemble activity. Journal of Neuroscience, 9(8), 2764-2775.

38. Milgrom, P., \& Roberts, J. (1988). Economic theories of the firm: past, present, and future. Canadian Journal of Economics, 444-458.

39. Helweg-Larsen, K., Kruse, M., Sørensen, J., \& Brønnum-Hansen, H. (2010). The costs of violence: Economic and personal dimensions of violence against women in Denmark. Syddansk Universitet. Statens Institut for Folkesundhed.
40. Peh, D., Hague, N., \& Tatchell, J. (2011). BIRT: a field guide. Addison-Wesley Professional.

41. Cinnamon, B., \& Helweg-Larsen, B. (2010). How to understand business finance. Kogan Page Publishers.

42. Baveld, M. B. (2012). Impact of working capital management on the profitability of public listed firms in The Netherlands during the financial crisis (Master's thesis, University of Twente).

43. Uyar, A. (2009). The relationship of cash conversion cycle with firm size and profitability: an empirical investigation in Turkey. International Research Journal of Finance and Economics, 24(2), 186-193.

44. Samiloglu, F., \& Demirgunes, K. (2008). The effect of working capital management on firm profitability: Evidence from Turkey. The International journal of applied Economics and Finance, 2(1), 44-50.

45. Myers, S., \& Majluf, N. (1984). Corporate financing decisions when firms have investment information that investors do not. Journal of Financial Economics, 13(2), 187-221.

46. Wesley, O. N., Musiega, M. G., Douglas, M., \& Atika, M. G. (2013). Working Capital Management And Corporate Performance. Special Reference To Manufacturing Firms On Nairobi Securities Exchange. International Journal of Innovative Research \& Development, 2, 177-183.

47. Smith, M. B., \& Begemann, E. (1997). Measuring associations between working capital and return on investment. South African Journal of Business Management, 28(1), 1-5.

48. Ghosh, S. K., \& Maji, S. G. (2003). Utilization of current assets and operating profitability: An empirical study on cement and tea industries in India. Indian Journal of Accounting, IAA, 81-91.

49. Eljelly, A. M. (2004). Liquidity- profitability tradeoff: An empirical investigation in an emerging market. International journal of commerce and management, 14(2), 48-61.

50. Boisjoly, R. P. (2009). The cash flow implications of managing working capital and capital investment. The Journal of Business and Economic Studies, 15(1), 98.

51. Brealey, R., \& Myers, S. (2006). Allen. Working capital management, corporate finance. Newyork: Mcgraw Hill.

52. Arnold, G. (2008). Corporate Financial Management. $3^{\text {rd }}$ Ed. England: Pearson Education Limited.

53. Ferris, J. S. (1981). A transactions theory of trade credit use.The Quarterly Journal of Economics, 96(2), 243-270.

54. Schwartz, A. M., \& Schimmel, P. R. (1974). Relaxation spectra of the iron spin transition in methemoglobin. Journal of molecular biology, 89(3), 505-510.

55. Frank, M., \& Maksimovic, V. (1998). Trade credit, collateral, and adverse 
selection. Unpublished manuscript, University of Maryland.

56. Gill, A., Biger, N., \& Mathur, N. (2010). The relationship between working capital management and profitability: Evidence from the United States. Business and economics journal, 10(1), 19.

57. Lincoln, J. E., Cordes, S., Read, E., \& Fischer, R. L. (1987). Regulation of gene expression by ethylene during Lycopersicon esculentum (tomato) fruit development. Proceedings of the National Academy of Sciences, 84(9), 2793-2797.

58. Mugenda, O., \& Mugenda, A. (2003). Research methods: Quantitative and qualitative approaches. 2nd. Nairobi: Nairobi: Act press pp45-49.

59. Creswell, J. W., Plano Clark, V. L., Gutmann, M. L., \& Hanson, W. E. (2003). Advanced mixed methods research designs. Handbook of mixed methods in social and behavioral research, 209, 240.

60. Kothari, A., \& Sagar, V. (2008). Antibiotic resistance in pathogens causing communityacquired urinary tract infections in India: a multicenter study. The Journal of Infection in Developing Countries, 2(05), 354-358.

61. Bell, E., \& Bryman, A. (2007). The ethics of management research: an exploratory content analysis. British journal of management, 18(1), 63-77.

62. Sekaran, C. B., \& Rani, A. P. (2010). Development and validation of spectrophotometric method for the determination of DPP-4 inhibitor, sitagliptin, in its pharmaceutical preparations. Eclética Química, 35(3), 45-53.

63. Orodho, A. J. (2003). Essentials of educational and social sciences research method. Nairobi: Masola Publishers.

64. Cooper, D. R., \& Schindler, P. S. (2003). Business Research Methods International Edition McGraw Hill.

65. Malhotra, M. K., \& Grover, V. (1998). An assessment of survey research in POM: from constructs to theory. Journal of operations management, 16(4), 407-425.

66. Patton, G. C., Coffey, C., Carlin, J. B., Degenhardt, L., Lynskey, M., \& Hall, W. (2002). Cannabis use and mental health in young people: cohort study. Bmj, 325(7374), 1195-1198.

67. Creswell, J. W. (2002). Educational research: Planning, conducting, and evaluating quantitative (pp. 146-166). Upper Saddle River, NJ: Prentice Hall.

68. Degeneff, R. C., McNutt, W. J., Neugebauer, W., Panek, J., McCallum, M. E., \& Honey, C. C. (1982). Transformer response to system switching voltages. IEEE Transactions on Power Apparatus and Systems, (6), 1457-1470.

69. Warfield, D. (2010). IS/IT Research: A Research Methodologies Review. Journal of Theoretical \& Applied Information Technology, 13.

70. Kvale, S. (2007). Contradictions of assessment for learning in institutions of higher learning. In Rethinking assessment in higher education (pp. 67-81). Routledge.

71. Cooper, D. R., \& Schindler, P. S. (2011). Qualitative research. Business research methods, 4(1), 160-182.

72. Cronbach, L. J. (1951). Coefficient alpha and the internal structure of tests. psychometrika, 16(3), 297-334.

73. Amin, S. M., \& Wollenberg, B. F. (2005). Toward a smart grid: power delivery for the $21 \mathrm{st}$ century. IEEE power and energy magazine, 3(5), 34-41.

74. Patten, C. J., Kircher, A., Östlund, J., \& Nilsson, L. (2004). Using mobile telephones: cognitive workload and attention resource allocation. Accident analysis \& prevention, 36(3), 341-350.

75. Wallen, N. E., \& Fraenkel, J. R. (2001). Educational research: A guide to the process.

76. Ali, A., Namusonge, G., \& Sakwa, M. (2016). Effect of Firm Managerial Risk Aversion on Corporate Hedging of Listed Firms in Nairobi Securities Exchange in Kenya. IJRDO-Journal of Business Management, 2 (7), 45, 64

77. Ochs, J., \& Roth, A. E. (1989). An experimental study of sequential bargaining. The American Economic Review, 355-384.

78. Mugenda, O. M., \& Mugenda, A. G. (2008). Research methodology. Qualitative and Quantitative Methods. Social Science Research: Theory and Principles.

79. Gitman, L., Chorn, B., \& Fargo, B. (2009). ESG in the mainstream: the role for companies and investors in environmental, social, and governance integration. San Francisco, CA: Business for Social Responsibility. 